\title{
Mathematical Model of a Personalized Neoantigen Cancer Vaccine and the Human Immune System: Evaluation of Efficacy
}

\author{
Marisabel Rodriguez Messan ${ }^{1}$, Osman N. Yogurtcu ${ }^{1}$, Joseph R. McGill ${ }^{2}$, Ujwani Nukala ${ }^{1}$, \\ Zuben E. Sauna ${ }^{2}$, Hong Yang ${ }^{1 *}$ \\ ${ }^{1}$ Office of Biostatistics and Epidemiology, Center for Biologics Evaluation and Research, US \\ FDA, Silver Spring, MD, USA \\ ${ }^{2}$ Office of Tissues and Advanced Therapies, Center for Biologics Evaluation and Research, US \\ FDA, Silver Spring, MD, USA \\ * Corresponding author \\ E-mail: Hong.Yang@fda.hhs.gov
}

\section{Abstract}

Cancer vaccines are an important component of the cancer immunotherapy toolkit enhancing immune response to malignant cells by activating $\mathrm{CD} 4^{+}$and $\mathrm{CD} 8^{+} \mathrm{T}$ cells. Multiple successful clinical applications of cancer vaccines have shown good safety and efficacy. Despite the notable progress, significant challenges remain in obtaining consistent immune responses across heterogeneous patient populations, as well as various cancers. We present as a proof of concept a mechanistic mathematical model describing key interactions of a personalized neoantigen cancer vaccine with an individual patient's immune system. Specifically, the model considers the vaccine concentration of tumor-specific antigen peptides and adjuvant, the patient's major histocompatibility complexes I and II copy numbers, tumor size, T cells, and antigen presenting cells. We parametrized the model using patient-specific data from a recent clinical study in 
medRxiv preprint doi: https://doi.org/10.1101/2021.01.08.21249452; this version posted June 6, 2021. The copyright holder for this preprint

(which was not certified by peer review) is the author/funder, who has granted medRxiv a license to display the preprint in perpetuity.

It is made available under a CC-BY-NC-ND 4.0 International license .

which individualized cancer vaccines were used to treat six melanoma patients. Model simulations predicted both immune responses, represented by $\mathrm{T}$ cell counts, to the vaccine as well as clinical outcome (determined as change of tumor size). These kinds of models have the potential to lay the foundation for generating in silico clinical trial data and aid the development and efficacy assessment of personalized cancer vaccines.

\section{Author summary}

Personalized cancer vaccines have gained attention in recent years due to the advances in sequencing techniques that have facilitated the identification of multiple tumor-specific mutations. This type of individualized immunotherapy has the potential to be specific, efficacious, and safe since it induces an immune response to protein targets not found on normal cells. This work focuses on understanding and analyzing important mechanisms involved in the activity of personalized cancer vaccines using a mechanistic mathematical model. This model describes the interactions of a personalized neoantigen peptide cancer vaccine, the human immune system and tumor cells operating at the molecular and cellular level. The molecular level captures the processing and presentation of neoantigens by dendritic cells to the $\mathrm{T}$ cells using cell surface proteins. The cellular level describes the differentiation of dendritic cells due to peptides and adjuvant concentrations in the vaccine, activation, and proliferation of $\mathrm{T}$ cells in response to treatment, and tumor growth. The model captures immune response behavior to a vaccine associated with patient specific factors (e.g., different initial tumor burdens). Our model serves as a proof of concept displaying its utility in clinical outcomes prediction, lays foundation for developing in silico clinical trials, and aids in the efficacy assessment of personalized vaccines. 


\section{Introduction}

Cancer vaccines, alone or in conjunction with other immune modulators (e.g., checkpoint 2 inhibitors) are among the most promising therapeutic options for many human cancers [1, 2]. 3 This therapy employs either dendritic cells, T cells, DNA, RNA, viral vectors, proteins, 4 peptides, or tumor cell lysate. The goal is exploiting the patient's immune system to target 5 antigens expressed only on tumor cells, in order to selectively eliminate cancer cells $[1,3,5]$. 6 Therapeutic strategies that incorporate personalized cancer vaccines have gained attention due 7 to successes in targeting multiple tumor-specific mutations [6]. However, tumor gene expression 8 and mutations are immensely diverse, and how they affect outcomes for individual patients 9 remains poorly understood [7]. Tumor-specific antigens (TSAs), or neoantigens, carry the 10 amino acid substitutions derived from random somatic mutations that are expressed only on 11 tumor cell surface. These mutations are highly patient- and tumor-specific $[2,6,8,9,9$.

With the advent of accurate and inexpensive Next Generation Sequencing techniques, routine sequencing of the DNA and RNA from cancer cells has become possible. Subsequent 14 workflows using bioinformatic tools allow the identification of neo-sequences. These neo-sequences carry somatic mutations exhibiting sequences that are different from the wild type, and hence can be recognized as nonself by the host immune system, with a high probability of eliciting a cancer-specific immune response. From the large number of neo-sequences identified, the selection of the few neo-sequences to be used as neoantigens in cancer vaccines largely is based on the affinity of the neoantigens peptides to the patient's 20 major histocompatibility complex-I (MHC-I) and MHC-II proteins [7]. Individualized immunotherapies designed based on these principles have the potential to be specific, efficacious, and safe 9 11]. Eliciting immune responses to protein targets not found on normal cells reduces the probability of immune toxicities 9 . vaccines described above, significant challenges remain. Selection of the candidate neoantigen 26 based on peptide-MHC binding affinity focuses on just one step of a complex immunological 27 
cascade. The peptide-MHC engagement is a necessary, but not sufficient, step for the immune ${ }_{28}$ response to occur. More comprehensive models are required to effectively evaluate the potential 29 neo-sequences to select those that will be the most efficacious as peptide vaccines. These 30 strategies must have a rapid turnaround time, as the window of opportunity to treat an 31 advanced cancer patient is limited. Also, there is lack of qualified predictive biomarkers for 32 determining whether the therapy will be effective. Quantitative modeling approaches provide a 33 useful toolkit for studying the interplay between tumor cells and the immune system [12]. 34 These approaches enable a quantitative understanding of immune response kinetics following 35 neoantigen-based peptide vaccine treatment. Insights gained from challenges can be used to 36 design better vaccines and evaluate the potential candidate vaccines in silico. The models also 37 can guide such decisions on treatment regimens such as dosing and infusion frequencies 13 . 38

Mathematical modeling in biology and medicine, especially oncology 14, 15, can be a powerful tool for the generation of experimental and clinical hypotheses to aid in study design [16, 17]. A mathematical model simplifies complex biological systems, provides insights ${ }_{41}$ into known mechanisms of the systems, and can aid researchers and clinicians better understand the disease and treatment 13,17 . Models can facilitate in the development of testable hypotheses by providing quantitative estimates for numerous outcomes produced by 44 dynamic interactions between various biological mechanisms. To date, several mathematical 45 models have been developed to predict the effect of mono or combination immunotherapies 46 against cancer $13,18,25$. Although these studies provide insights into the interactions between $\quad 47$ treatments and immune response by modeling cell- and/or tissue-level immune dynamics, 48 components of immune dynamics at the molecular level are lacking. The addition of this level 49 of granularity to a mathematical model describing the immune and clinical response to a cancer 50 vaccine is critical. Key molecular events that may impact the immune response and clinical 51 outcome include, antigen processing and presentation, and MHC-T cell binding. Thus, a model 52 that successfully describes the immune response elicited by a cancer vaccine (and the 53 subsequent effect on tumors) will need to include the molecular parameters and events that 54 drive the immunological cascade. The model presented here addresses this critical unmet need. $\quad 55$ 


\section{Results}

\section{Model parametrization for individual patients based on their $\mathbf{T}$ cell response $\quad 57$}

Our mathematical model is designed to quantify the effect of a personalized peptide cancer 58 vaccine, which is a mixture of peptide neoantigens with an adjuvant, on (1) T cell response and 59 (2) change in tumor size. To parametrize our model, we fitted the six individual patients' 60 longitudinal $\mathrm{T}$ cell response data extracted from a published study [26] as described in the ${ }_{61}$ Supplementary S1 Appendix to obtain patient-specific initial conditions and model parameters, 62 i.e., an individual patient's T cell response to peptides, initial tumor cell count, HLA alleles, ${ }_{63}$ and the peptide amino acid sequences of the personalized vaccine. Patients' activated T cell 64 counts data over time and the model fits with the highest adjusted $R^{2}$ are shown in Fig 1 . The ${ }_{65}$ patient-specific best-fit parameter values are tabulated in Table 1. Detailed description of these ${ }_{66}$ parameters (labeled with $\star$ ) is on Supplementary S1 Table.

Table 1. Best-fit values of model parameters for six melanoma patients in study $[\mathbf{2 6}]$. $c$ : Maximum CD8 $\mathrm{T}$ cells recruitment rate; $c_{4}$ : Maximum $\mathrm{CD} 4^{+} \mathrm{T}$ cell production rate; $d$ : Maximum lysis rate by activated $\mathrm{T}$ cells; $\lambda$ : dependence of lysis rate on the effector/target ratio constant. [95\% CI ${ }^{*}$ denotes modified confidence interval by replacing negative lower endpoint with zero as described in [27].

\begin{tabular}{|c|c|c|c|c|c|c|}
\hline & $\begin{array}{c}\text { PATIENT 1 } \\
\text { Point Estimate } \\
\text { SE } \\
{[95 \% \mathrm{CI}]}\end{array}$ & $\begin{array}{c}\text { PATIENT 2 } \\
\text { Point Estimate } \\
\text { SE } \\
{[95 \% \mathrm{CI}]}\end{array}$ & $\begin{array}{c}\text { PATIENT 3 } \\
\text { Point Estimate } \\
\text { SE } \\
{[95 \% \mathrm{CI}]}\end{array}$ & $\begin{array}{c}\text { PATIENT } 4 \\
\text { Point Estimate } \\
\text { SE } \\
{[95 \% \mathrm{CI}]}\end{array}$ & $\begin{array}{c}\text { PATIENT 5 } \\
\text { Point Estimate } \\
\text { SE } \\
{[95 \% \mathrm{CI}]}\end{array}$ & $\begin{array}{c}\text { PATIENT } 6 \\
\text { Point Estimate } \\
\text { SE } \\
{[95 \% \mathrm{CI}]}\end{array}$ \\
\hline$c$ & $\begin{array}{c}0.0156 \\
0.0088 \\
{[0,0.054]^{*}}\end{array}$ & $\begin{array}{c}0.0084 \\
0.0596 \\
{[0,0.198]^{*}}\end{array}$ & $\begin{array}{c}0.0448 \\
0.0814 \\
{[0,0.304]^{*}}\end{array}$ & $\begin{array}{c}0.0056 \\
0.035 \\
{[0,0.117]^{*}}\end{array}$ & $\begin{array}{c}0.031 \\
0.035 \\
{[0,0.142]^{*}}\end{array}$ & $\begin{array}{c}5.55 \times 10^{-5} \\
0.00141 \\
{[0,0.006]^{*}}\end{array}$ \\
\hline$c_{4}$ & $\begin{array}{c}0.04 \\
0.037 \\
{[0,0.203]^{*}}\end{array}$ & $\begin{array}{c}0.0105 \\
0.0453 \\
{[0,0.155]^{*}}\end{array}$ & $\begin{array}{c}0.0487 \\
0.0098 \\
{[0.017,0.08]}\end{array}$ & $\begin{array}{c}0.0467 \\
0.012 \\
{[0.008,0.085]}\end{array}$ & $\begin{array}{c}0.0327 \\
0.0145 \\
{[0,0.079]^{*}}\end{array}$ & $\begin{array}{c}0.04224 \\
0.013 \\
{[0,0.0984]^{*}}\end{array}$ \\
\hline$d$ & $\begin{array}{c}0.068 \\
0.008 \\
{[0.032,0.105]}\end{array}$ & $\begin{array}{c}0.0196 \\
0.045 \\
{[0,0.163]^{*}}\end{array}$ & $\begin{array}{c}0.0649 \\
0.008 \\
{[0.039,0.091]}\end{array}$ & $\begin{array}{c}0.0617 \\
0.0347 \\
{[0,0.172]^{*}}\end{array}$ & $\begin{array}{c}0.0525 \\
0.0234 \\
{[0,0.127]^{*}}\end{array}$ & $\begin{array}{c}0.035 \\
0.119 \\
{[0,0.545]^{*}}\end{array}$ \\
\hline$\lambda$ & $\begin{array}{c}0.978 \\
0.015 \\
{[0.914,1.041]}\end{array}$ & $\begin{array}{c}0.991 \\
0.074 \\
{[0.755,1.226]}\end{array}$ & $\begin{array}{c}1 \\
0.0479 \\
{[0.848,1.152]}\end{array}$ & $\begin{array}{c}0 \\
1.43 \times 10^{-11} \\
{\left[0,4.5 \times 10^{-11}\right]^{*}}\end{array}$ & $\begin{array}{c}0.8568 \\
0.038 \\
{[0.736,0.978]}\end{array}$ & $\begin{array}{c}1.41 \times 10^{-4} \\
0.0257 \\
{[0,0.111]^{*}}\end{array}$ \\
\hline $\begin{array}{c}\text { Adjusted } \\
R^{2}\end{array}$ & 0.756 & 0.897 & 0.899 & 0.952 & 0.739 & 0.796 \\
\hline
\end{tabular}



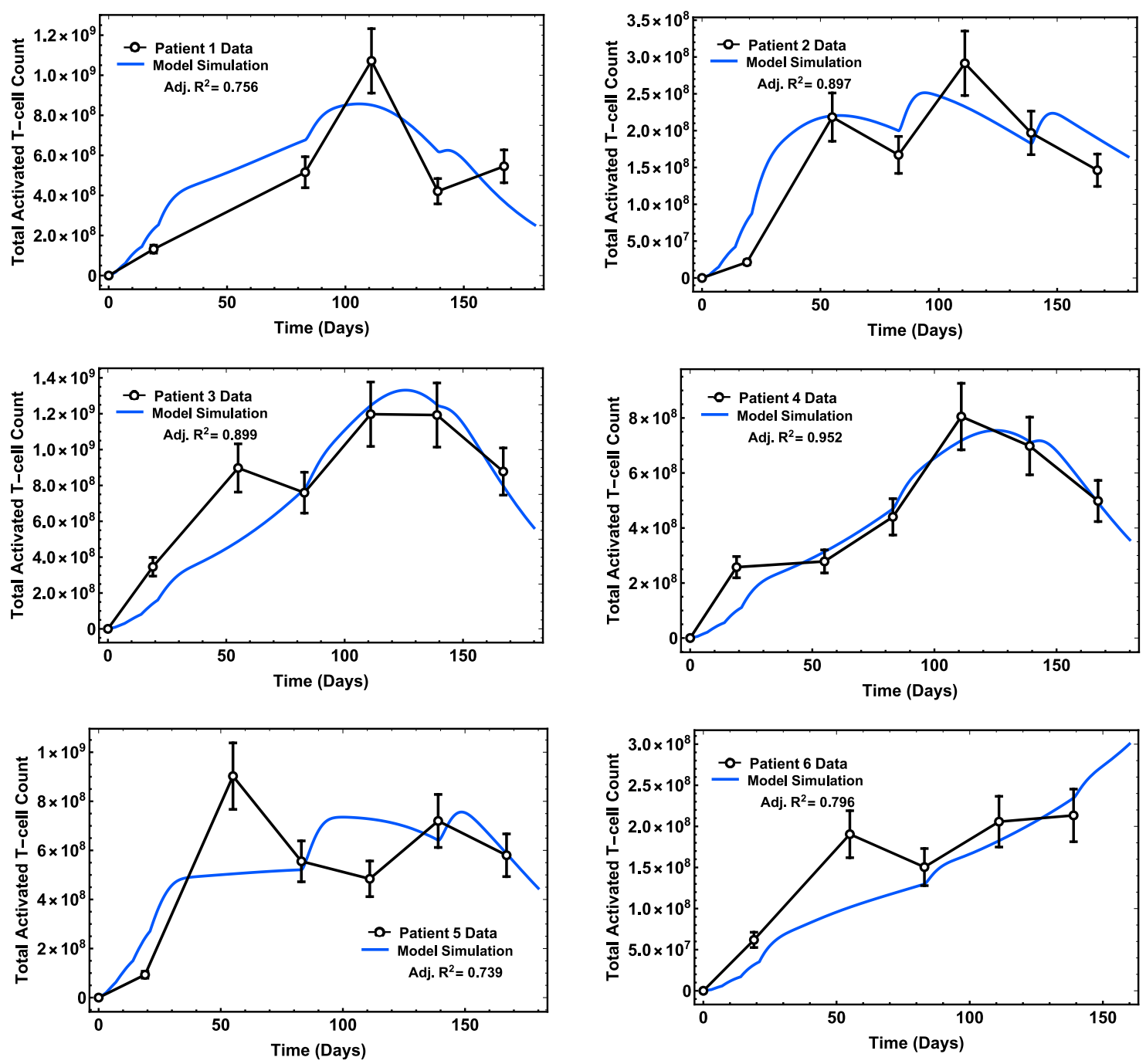

Fig 1. Time profiles of $\mathbf{T}$ cell response of patients. Model fits with the highest adjusted $R^{2}$ are plotted alongside clinical data from a Phase 1 study [26] (open circles with error bars, $15 \%$ standard error measurement; see S1 Appendix for details; blue arrows indicate days when prime and booster vaccine doses were administered).

\section{Longitudinal model forecasts of change of tumor size in clinical trial patients}

To further explore the utility of our model, we used the best-fit parameter values in Table 1 to $\quad{ }^{69}$ predict the change of tumor size of individual patients. The clinical trial [26], briefly reported 70 that four patients $(1,3,4$, and 5), initially diagnosed with Stage 3 melanoma, exhibited no 71 recurrence of the disease following the treatment regimen with the cancer vaccine. On the other 72 hand, patients 2 and 6, initially diagnosed with Stage 4 melanoma, showed disease recurrence 73 after the vaccine treatment. Using each patient's best-fit parameter values (Table 1), we 
medRxiv preprint doi: https://doi.org/10.1101/2021.01.08.21249452; this version posted June 6, 2021. The copyright holder for this preprint (which was not certified by peer review) is the author/funder, who has granted medRxiv a license to display the preprint in perpetuity.

It is made available under a CC-BY-NC-ND 4.0 International license .

simulated the tumor cell dynamics under influence of the vaccine. We computationally

estimated the tumor size (diameter in millimeters; cell counts highlighted in yellow) 200 days 76 after treatment initiation for all six patients (see Fig 2). For patients 2 and 6 , we further 77 compared model-predicted tumor size at days 196 and 146, respectively, with CT scan images 78 and sizes obtained in the study [26] at these two time points, respectively.
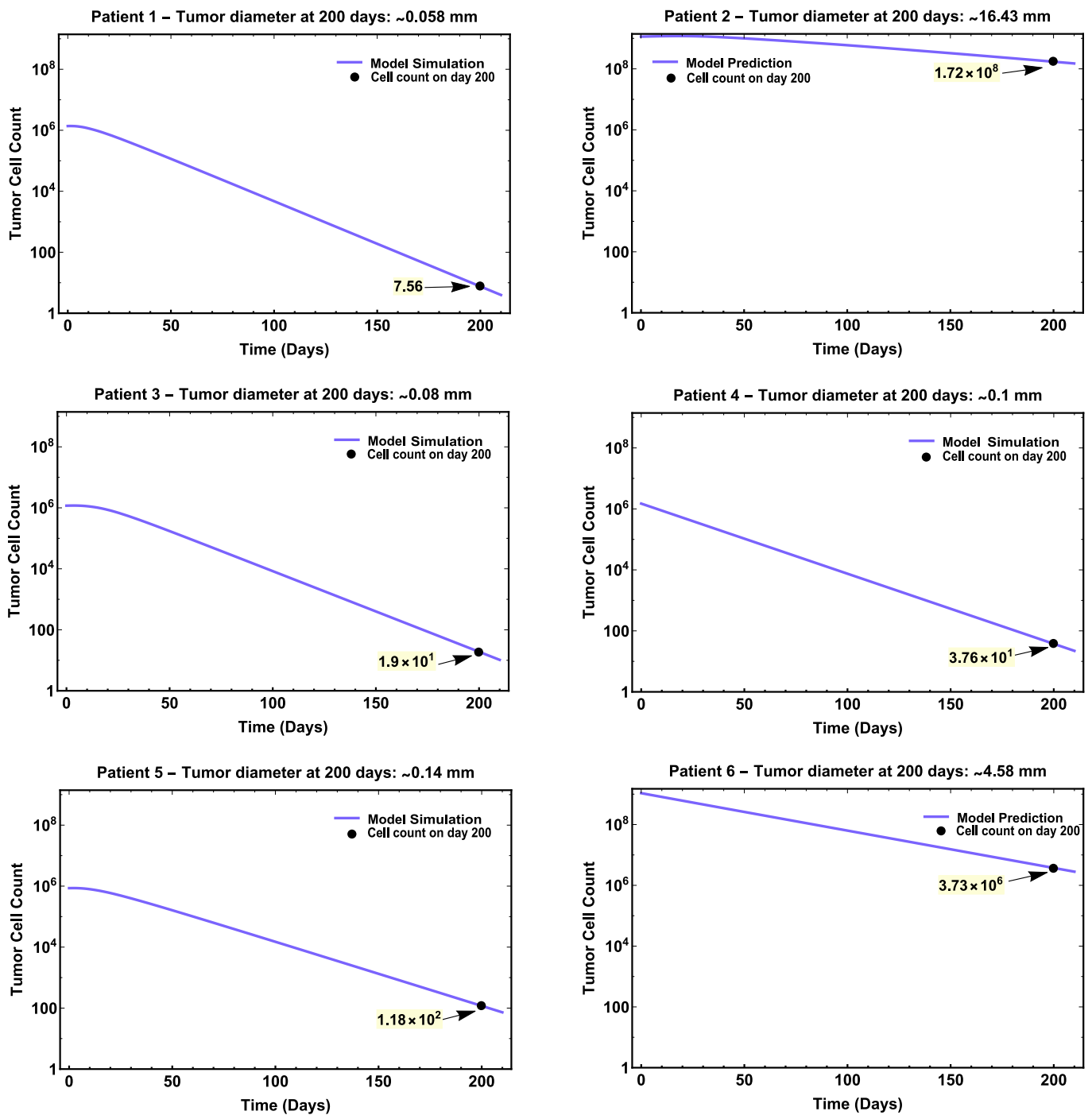

Fig 2. Longitudinal tumor burden predictions for patients 1-6 with quantitative tumor diameter predictions on day 200. Model simulations are plotted in log-scale with respect to tumor cell count. Model-predicted malignant cell count on specified day (black dot) is shown highlighted in yellow and tumor size (diameter) was estimated in millimeters from tumor cell count.

Model predictions of tumor size for patient 1, 3, 4, and 5 (no reported disease recurrent) 
showed a relatively greater decrease of tumor size (or cell count) with respect to patients 2 and 81 6 (with report of disease recurrent) at the end of vaccine treatment. Our model predictions on 82 residual malignancies are qualitatively consistent with reported clinical are consistent of 83 non-recurrence versus recurrence (see Fig 2).
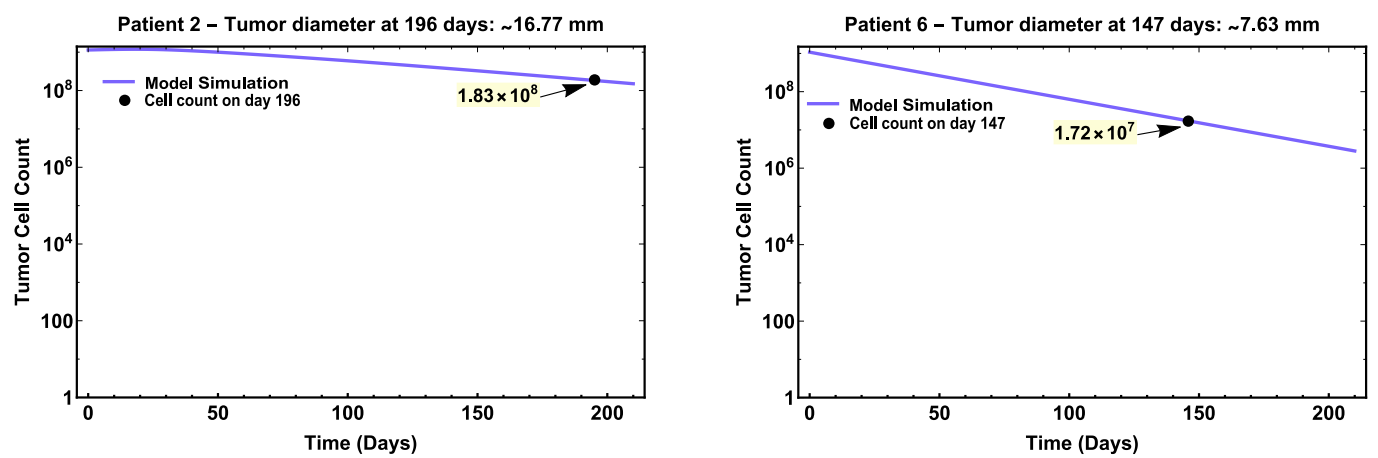

Fig 3. Longitudinal tumor burden predictions Patients 2 and 6 with quantitative tumor diameter predictions on day 196 and 147, respectively. Model simulations are plotted in log-scale with respect to tumor cell count. Model-predicted malignant cell count on specified day (black dot) is shown highlighted in yellow and tumor size (diameter) was estimated in millimeters from tumor cell count.

The CT scans for Patient 2 were obtained 8 weeks after last booster vaccine (day 196)

For Patient 6, CT scans were obtained one week after last booster vaccine, that is on day 147 (assuming vaccine was administered on day 140 corresponding to week 20 of vaccination

\section{Sensitivity analysis}

To explore the behavior of this complex mathematical model, we performed a global sensitivity 
parameter values obtained from different sources, unknown errors in the input data, and errors 97 in model solution algorithms. Using sensitivity analysis, we can quantify how a change in the 98 value of an input parameter changes the value of the outcome variable. The sensitivity analysis 99 thus allows the identification of parameters that make major contributions to the uncertainty of 100 the outcomes 28.

For all patients, the sensitivity of the outcome variable $A_{T C}$ has shown to be consistently $\quad{ }_{102}$ high throughout three time points (days $25,112,147$ ) to the parameter $c_{4}$ (maximum $\mathrm{CD} 4^{+} \mathrm{T} \quad{ }_{103}$ cell production rate stimulated by the interactions with tumor cells), since $\left|P R C C\left(A_{T C}, c_{4}\right)\right| \approx 1$, i.e., magnitude of the $\mathrm{PRCC}$ value of parameter $c_{4}$ with respect to the 105 output of interest $A_{T C}$ is close to 1 . Also, for all patients, the variable $A_{T C}$ was shown to be 106 sensitive to the parameter $d$ (maximum killing rate by activated $\mathrm{CD} 8^{+} \mathrm{T}$ cells), i.e., $\quad{ }_{107}$ $\left|\operatorname{PRCC}\left(A_{T C}, d\right)\right| \approx 1$. However, the sensitivity to parameter $d$ for Patient $1,3,4$, and 5 was 108 shown to increase over time, the opposite occurred for Patient 2 and 6. For individual patients 109 1,2 , and 6 , the variable $A_{T C}$ was shown to be sensitive to the parameter $c$ (maximum $\mathrm{CD} 8^{+} \mathrm{T} \quad{ }_{110}$ cells recruitment rate stimulated by interactions with tumor cells), in which sensitivity to $A_{T C}{ }_{111}$ to $c$ increased over time for Patient 2 and 6 .

\section{Activated T-cells $\left(\mathbf{A}_{\mathrm{TC}}\right)$}
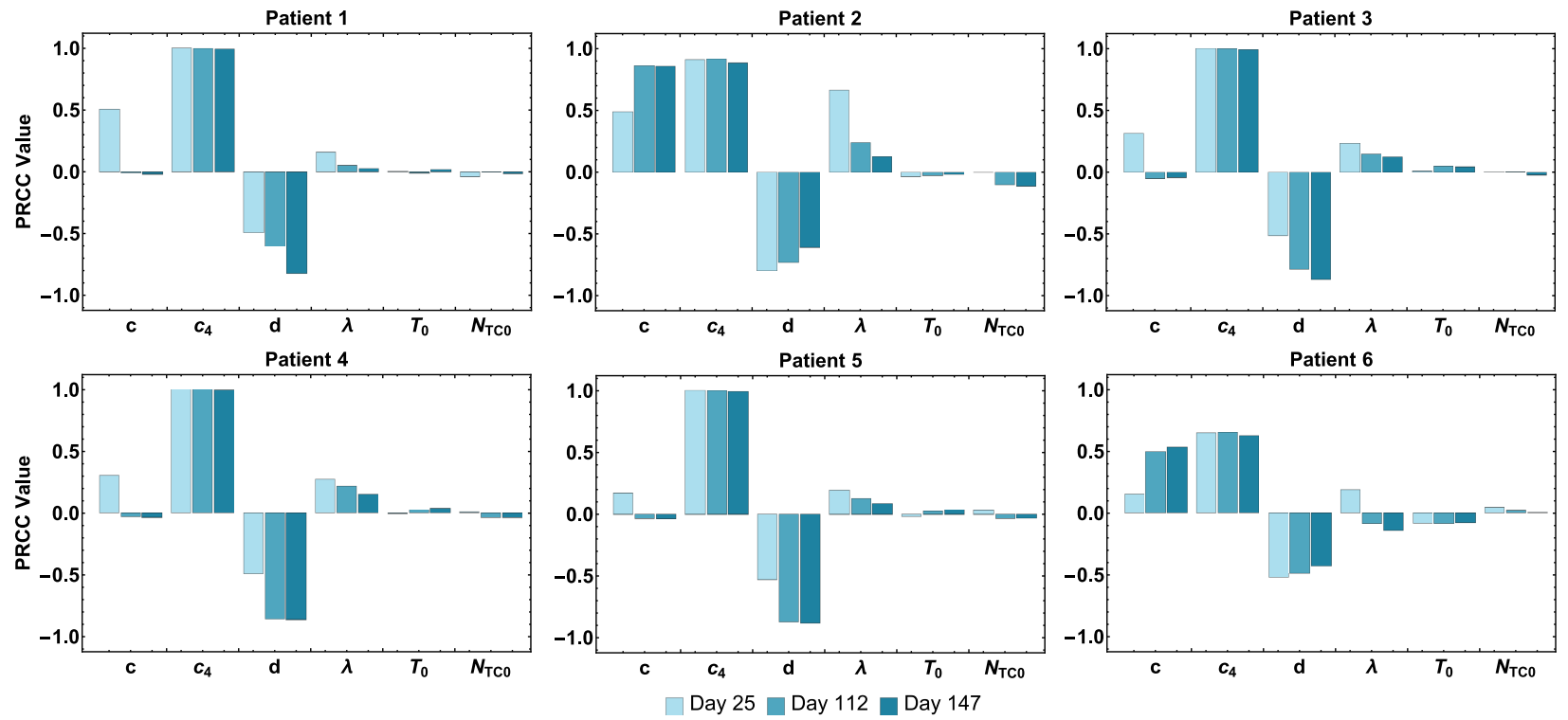

Fig 4. Activated T cell population sensitivity. PRCC values are shown for the estimated parameters using the total activated $\mathrm{T}$ cell population as the output of interest. 
For the second output of interest, tumor cells $(T)$, PRCC values show that $d$ (maximum $\quad 113$ tumor killing rate by activated $\mathrm{CD}^{+} \mathrm{T}$ cells) is consistently the most influential parameter for ${ }_{114}$ all patients and throughout each time point. The second most influential parameter to the 115 sensitivity of tumor cell counts for all patients at the 'priming phase' (day 25) is $\lambda$ (dependence 116 of killing rate on the effector/target ratio constant). For Patients 2 and 4, the variable for 117 tumor cells remains sensitive to parameter $\lambda$ at different PRCC values throughout the rest of ${ }_{118}$ the phases ('peak T cell response' and 'end of treatment').
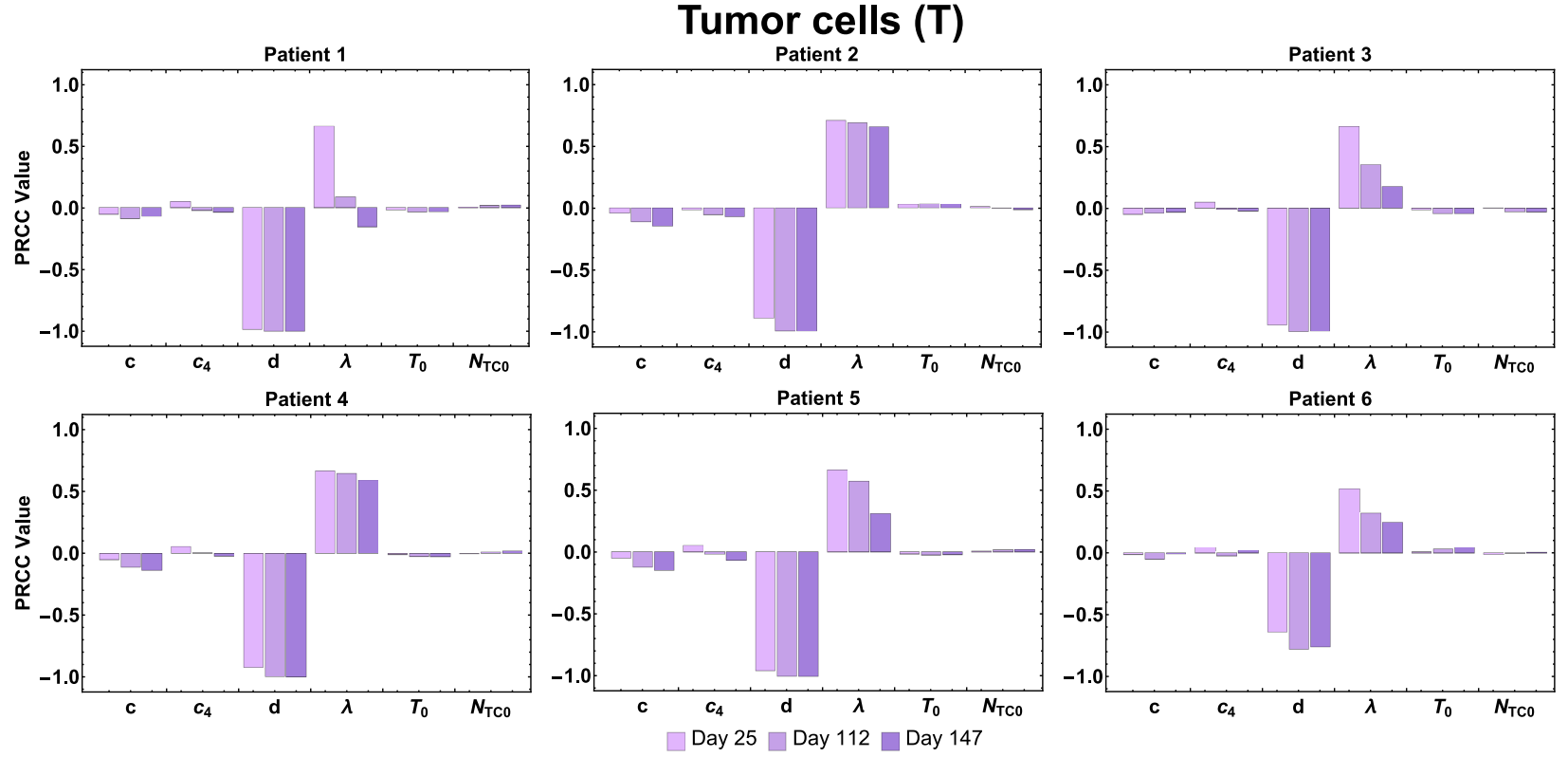

Fig 5. Tumor cell population sensitivity. PRCC values are shown for the estimated parameters using the tumor cell population as the output of interest.

However, this analysis revealed both variables of interest, activated T cells and tumor cells $\quad{ }_{120}$ $\left(A_{T C}\right.$ and $\left.T\right)$ were not sensitive, to initial counts of tumor cells $\left(T_{0}\right)$ and naïve $\mathrm{T}$ cells $\left(N_{T C 0}\right) \quad{ }_{121}$ for all the time points considered. 


\section{Application: impact of cancer vaccine treatment on clinical}

To explore the impact of vaccine administration at different initial tumor sizes, we predicted 125 tumor diameter size (or cell count) 20 days after the last vaccination was administered (day ${ }_{126}$ 168) as a surrogate marker for clinical outcome. We selected four critical tumor diameters based ${ }_{127}$ on total cell counts at time of vaccination and made predictions using individual patient data ${ }_{128}$ and settings. Methodological details for generating Fig 6 6 can be found in the Supplementary S1 129 Appendix.

In Fig 6, we can observe different outcomes for patients based on their profiles (i.e., HLA 131 alleles, peptide-vaccine concentration, estimated patient-specific parameters). Fig 6A, for ${ }_{132}$ example, shows that all patients are able to achieve optimal tumor size reduction to less than $1{ }_{133}$ $\mathrm{mm}$ in diameter after vaccination if they start treatment when the tumor has a diameter of less 134 than $2.4 \mathrm{~mm}$. If patients start treatment when the tumor has a diameter larger than $2.4 \mathrm{~mm} \quad{ }_{135}$ but smaller than $6.4 \mathrm{~mm}$, we predict (Fig $6 \mathrm{~B}$ ) that tumor sizes of patients $1,3,4,5$, and $6 \quad 136$ would be smaller compared to Patient 2. In Fig 6C, Patients 1, 3, 4, and 5, starting treatment 137 when tumor diameter is between 6.4 and $23.45 \mathrm{~mm}$, are shown to achieve optimal tumor size 138 reduction to less than $1 \mathrm{~mm}$ in diameter. Finally, Fig 6D, shows that patients who start vaccine 139 treatment with a much larger tumor size $(>23.6 \mathrm{~mm})$ are not able to reach an optimal tumor $\quad 140$ size reduction at the end of treatment.

\section{Discussion}

Cancer vaccines have the potential to enhance the immune response to target and eliminate 

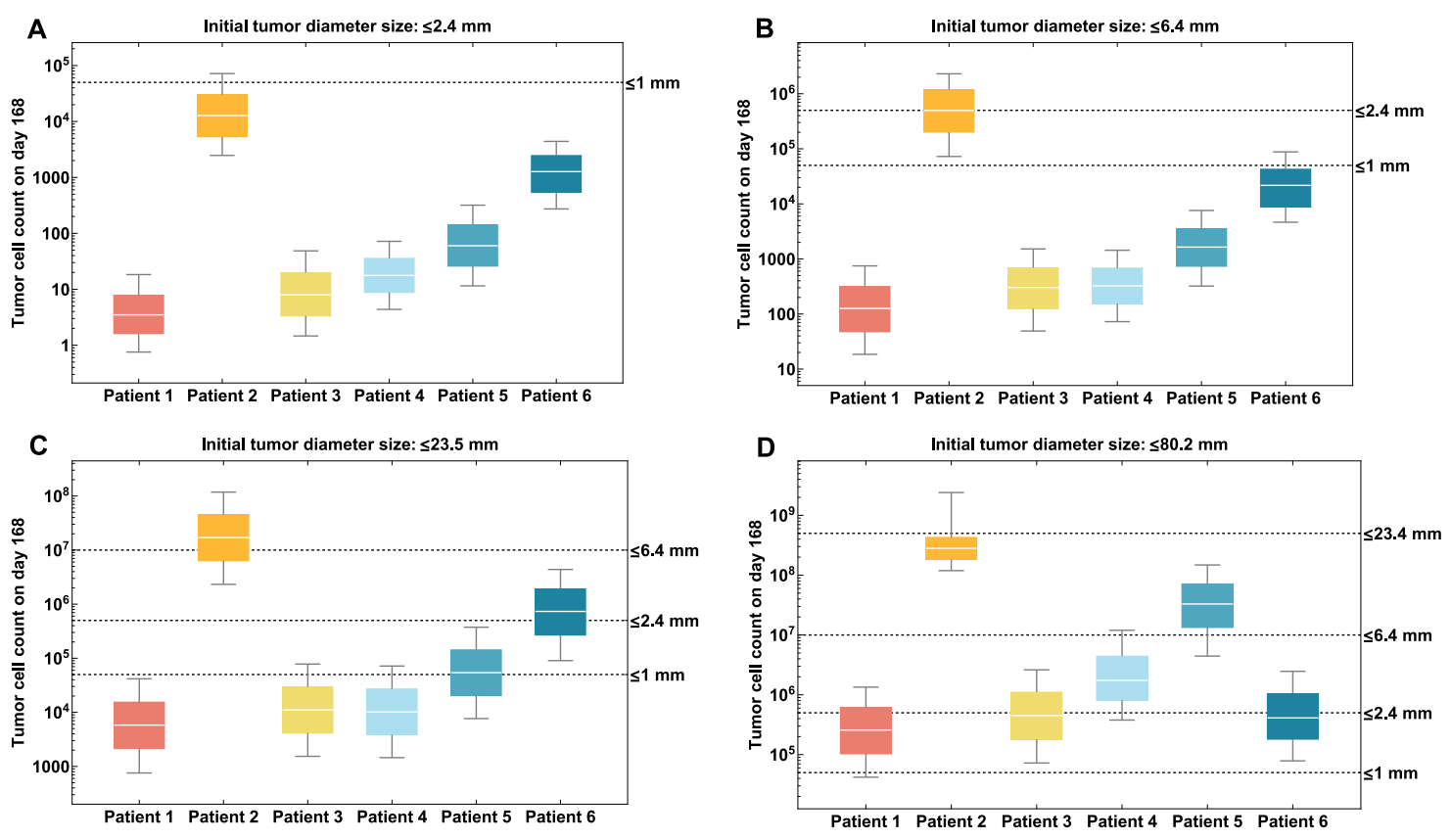

Fig 6. Prediction of tumor diameter by patient according to different initial tumor size at time of clinical trial enrollment. (a) Initial tumor diameter is less than or equal to $2.4 \mathrm{~mm}$; (b) Initial tumor diameter is larger than $2.4 \mathrm{~mm}$ but smaller or equal to 6.4 $\mathrm{mm}$; (c) Initial tumor diameter is larger than $6.4 \mathrm{~mm}$ but smaller or equal to $23.45 \mathrm{~mm}$. (d) Initial tumor diameter is larger than $23.45 \mathrm{~mm}$ but smaller or equal to $80.2 \mathrm{~mm}$.

behavior to a vaccine associated with patient specific factors (e.g., different initial tumor burdens).

Our model currently includes a phenomenological response as a means to simulate killing of tumor cells. Also, we assumed the logistic functional form to represent tumor growth. ${ }^{157}$

Usually, the choice of a tumor growth function in general is determined by clinical data, ${ }_{158}$ which can vary depending on the type of tumor, location, and disease stage, among other 
medRxiv preprint doi: https://doi.org/10.1101/2021.01.08.21249452; this version posted June 6, 2021. The copyright holder for this preprint

(which was not certified by peer review) is the author/funder, who has granted medRxiv a license to display the preprint in perpetuity.

It is made available under a CC-BY-NC-ND 4.0 International license .

factors [34]. Several studies $13,22,31,34$ have suggested that the logistic and Gompertz 160 functions are the most suitable for modeling tumor growth. Both functions have exhibited good 161 predictions when calibrated with experimental data, usually from animal models of breast, lung, 162 and melanoma cancers $13,22,31,34]$. Our choice was based on the simplicity of the logistic 163 function, as it only requires the estimation of two, rather three parameters in the Gompertz 164 function, and the lack of longitudinal clinical data.

The model was calibrated through model fitting using individual patient data from a clinical 166 trial study [26]. We fitted the model on parameters $c, c_{4}, d$, and $\lambda$ (see Table 1). These model 167 parameters describe the killing and proliferation interactions between activated T cells and 168 tumor cells, which were modeled based on phenomenological assumptions. We employed global 169 optimization to find the best fit model parameter values to individual patient data. We selected 170 adjusted $R^{2}$ as our goodness-of-fir measure. The adjusted $R^{2}$ ranged from 0.74 to 0.95 across 171 the model fits for the six patients. Model fits to patient 1, 5, and 6 data resulted with a lower 172 adjusted $R^{2}$ ( 0.7$)$ which may be due to fewer number of data points compared to the rest of $\quad 173$ the patients (6 vs. 7 data points). Patient 5 data had the lowest adjusted $R^{2}$ and it may be $\quad 174$ partially attributable to a much earlier peak T cell response comparing to the rest of the 175 patients.

Our model was used to show some possible applications, such as the longitudinal tumor size 177 change forecast for individual patients undergoing melanoma treatment and the prediction of 178 clinical outcome given initial tumor stage (size) when receiving the vaccine. Using available 179 information on the individual patient's tumor stage and clinical history, we predicted that the 180 tumor size (diameter) 200 days after the first vaccination for all six patients. The predicted 181 tumor size of Patients 1, 3, 4, and 5 who had no report of disease recurrence on day 200 fell 182 under $1 \mathrm{~mm}$ in diameter, which is clinically declared a "thin" melanoma, and is considered a 183 favorable outcome with a low risk of cancer spreading [35]. This model prediction is consistent 184 with the clinical reports of those patients. For Patients 2 and 6, we compared model predicted 185 tumor size with measurement from CT scans. Though model predicted tumor size for Patients 186 2 and 6 was slightly off from CT scans measurement, the model predicted increases of tumor $\quad{ }_{187}$ 
medRxiv preprint doi: https://doi.org/10.1101/2021.01.08.21249452; this version posted June 6, 2021. The copyright holder for this preprint

(which was not certified by peer review) is the author/funder, who has granted medRxiv a license to display the preprint in perpetuity.

It is made available under a CC-BY-NC-ND 4.0 International license .

sizes for these two patients at day 200 illustrating their recurrence.

Moreover, this kind of model can also be used to compare different clinical options. For $\quad 189$ example, we used our model to explore the impact of vaccine treatment initiation after resection 190 surgery on tumor progression. Our results showed that the best-case scenario for treatment 191 initiation is when patients start vaccination with a tumor of less than or equal to $6.4 \mathrm{~mm}$ in 192 diameter (Fig 64A-B). In Fig 6B, we observed that 90\% of the patients achieved a tumor ${ }_{193}$ diameter of less than $1 \mathrm{~mm}$ at the end of treatment (favorable lesion); whereas in Fig 6A, 100\% 194 of patients' tumor size fell under $1 \mathrm{~mm}$. Therefore, the 'best' clinical outcome of a personalized 195 neoantigen peptide vaccine is when a patient starts treatment with a tumor diameter size of less 196 than $6.4 \mathrm{~mm}\left(1 \times 10^{7}\right.$ cells $)$.

Sensitivity analysis of our model using estimated parameters revealed the parameters which 198 have the greatest impact on total activated T cell count during vaccine treatment, as well as 199 final tumor size. The model variable for activated T cells $\left(A_{T C}\right)$ was found to be highly 200 sensitive throughout the treatment period (days 25, 112, 147) for all patients, to parameter $c_{4} 201$ (maximum CD4 ${ }^{+} \mathrm{T}$ cell production rate stimulated by the interactions with tumor cells). For ${ }_{202}$ patients 1,2 , and 6 , the variable $A_{T C}$ was shown to be sensitive to the parameter $c$ (maximum 203 $\mathrm{CD}^{+} \mathrm{T}$ cell recruitment rate stimulated by interactions with tumor cells). Proliferation (or 204 recruitment) of immune cells to the tumor site has been shown to be a favorable prognostic 205 sign [36]. Consistently, parameters in our model involved in the proliferation/recruitment of 206 immune cells show great influence on the efficiency of the immunotherapy in eliciting an 207 immune response. Also, for all patients, both variables, activated T cells $\left(A_{T C}\right)$ and tumor cells 208 $(T)$ were shown to be sensitive to the parameter $d$ (maximal killing rate by activated $\mathrm{CD} 8^{+} \mathrm{T}{ }_{209}$ cells. This result shows the importance of this parameter, as it may help determine how 210 effective an immunotherapy can be in triggering the immune system to elicit tumor cytotoxicity. 211

The parametrization of our model was limited by the small number of patients from the ${ }_{212}$ clinical study used for model calibration, their limited follow-up times and lack of individual ${ }_{213}$ level longitudinal tumor cell count (or size) data. Potential future accumulation of patient data 214 
medRxiv preprint doi: https://doi.org/10.1101/2021.01.08.21249452; this version posted June 6, 2021. The copyright holder for this preprint

(which was not certified by peer review) is the author/funder, who has granted medRxiv a license to display the preprint in perpetuity.

It is made available under a CC-BY-NC-ND 4.0 International license.

would provide the opportunity for better characterization of patient-specific model parameters $\quad 215$ that can be tumor-stage specific. Both individual patient longitudinal tumor size and T cell ${ }_{216}$ response measurement might greatly improve model calibration and validation for a better $\quad 217$ clinical outcome prediction. However, we observed significant differences in parameters $a_{1}$ and ${ }_{218}$ $a_{2}$ which determine the efficiency of the immune system to recognize tumor cells and elicit an $\quad 219$ immune response. For example, the parameter values of $a_{1}$ and $a_{2}$ obtained by fitting the 'no $\quad 220$ recurrence' patients' data to our model were substantially smaller compared to the values of $a_{1}{ }_{221}$ and $a_{2}$ obtained through the fitting of the 'recurrence' patients' data. Another limitation of our 222 current parametrization approach is that certain parameters found in the literature may have ${ }_{223}$ associated uncertainty that could affect model outcome, such as errors in measurements or 224 natural variations. Though this variance in the parameters is not always reported in the 225 literature, we briefly explored how model variables of interest are affected by potential 226 variations of these parameters through global sensitivity analysis (see S1 Appendix section 227 B.8). It was found that both model variables of interest, activated T cells and tumor cells, are ${ }_{228}$ highly sensitive to parameters $\alpha_{p}, \Lambda$, and $\delta_{M}$ (internalization rate of peptides by DCs, ${ }_{229}$ maximum growth and death rate of mature DCs, respectively). In addition, the model variable ${ }^{230}$ for the activated $\mathrm{T}$ cell was found to be highly sensitive to $b_{4}, \sigma_{4}, \mu_{4}$, and $\mu_{8}$ (maximum growth 231 of naïve $\mathrm{CD} 4^{+} \mathrm{T}$ cells, maximum activation rate of CD4+ T cells, and death rate of activated ${ }_{232}$ $\mathrm{CD}^{+}$and $\mathrm{CD} 8^{+} \mathrm{T}$ cells, respectively). The model variable for tumor cells, also was found to ${ }_{233}$ be highly sensitive to $b_{8}, \sigma_{8}$, and $\rho_{8}$ (maximum growth of naïve $\mathrm{CD} 8^{+} \mathrm{T}$ cells, maximum ${ }^{234}$ activation rate $\mathrm{CD} 8^{+} \mathrm{T}$ cells, and proliferation rate for activated $\mathrm{CD} 8^{+} \mathrm{T}$ cells). ${ }^{235}$

Other limitations of our model include the consideration of key mechanisms related to the 236 efficacy of the vaccine. Although some recent studies 30,37 showed that CD4 ${ }^{+} \mathrm{T}$ cells may act ${ }_{237}$ directly and indirectly in killing tumor cells, we did not incorporate this mechanism into our 238 model. Our model incorporates the well-known mechanism of $\mathrm{CD}^{+} \mathrm{T}$ cells helping in the ${ }^{239}$ activation of $\mathrm{CD}^{+}$cytotoxic $\mathrm{T}$ cells in the presence of tumor cells. However, future versions of 240 this model may incorporate the assumption of $\mathrm{CD} 4^{+} \mathrm{T}$ cell's direct cytotoxicity against tumor ${ }_{241}$ cells if further evidence becomes available. We have not considered the tumor antigen escape 242 
phenomenon, and thus cannot model the potential outcomes if cancer cells stop expressing the 243 neoantigens used to formulate the vaccines. The current version of our model also does not 244 feature, concomitant therapies used against malignancies, as is usually the case in real-life 245 scenarios. Additionally, we have not incorporated T cell sub-types (e.g., memory, regulatory) or 246 antibody-mediated tumor eradication explicitly. We recognize that these are all important 247 considerations for our future work.

Another important potential addition to our model would be the incorporation of a 249 post-vaccine therapy, such as a checkpoint inhibitor, to enable continued tracking of the 250 patient's disease progression and determine possible safety and efficacy outcomes of individual 251 or combined treatments. Last, our model is not readily applicable in studying efficacy of 252 personalized neoantigen vaccines indicated in malignancies of the brain due to disease-specific ${ }_{253}$ constraints and the existence of the blood-brain barrier.

The current stage of the model serves as a proof of concept displaying its utility in clinical 255 outcomes prediction, lays foundation for developing in silico clinical trials, and aids in the 256 efficacy assessment of personalized vaccines. This model is flexible in the sense that its 257 structure may be modified to capture other key mechanisms involved in the interactions of the ${ }^{258}$ human immune system and personalized cancer immunotherapy, and it allows for exploration 259 and quantification of the impact of therapy initiation times on trial outcomes.

\section{Methods}

\section{Mathematical model}


medRxiv preprint doi: https://doi.org/10.1101/2021.01.08.21249452; this version posted June 6, 2021. The copyright holder for this preprint

(which was not certified by peer review) is the author/funder, who has granted medRxiv a license to display the preprint in perpetuity.

It is made available under a CC-BY-NC-ND 4.0 International license .

that embody essential aspects of a neoantigen vaccine and target patient cohorts. The model is 267 composed of a single immune system compartment encompassing the implicit connection of the ${ }_{268}$ innate and adaptive immunity. We consider two modeling levels, the cellular and subcellular (or 269 molecular). At the cellular level, we have cell populations such as, antigen presenting cells 270 (APCs), naïve and activated $\mathrm{CD} 4^{+}$and $\mathrm{CD} 8^{+} \mathrm{T}$ cells (helper and cytotoxic $\mathrm{T}$ cells, ${ }^{271}$ respectively), and tumor cells in the patient. One of the critical steps in vaccination is the 272 efficient presentation of the tumor-specific antigen (TSA) to the T cells. Dendritic cells (DCs) 273 are the most efficient APCs and we parametrized our APC model based on DCs. APCs capture, 274 process and present the antigens to the T cells using cell surface proteins, i.e., MHC class I and 275 II molecules. Engagement of the MHC-antigen complex with the T cell receptors (TCRs), 276 initiates the differentiation of antigen-specific $\mathrm{T}$ cells into effector $\mathrm{T}$ cells 38 . We model these 277 mechanisms and interactions at the cellular and subcellular levels.

Below, we describe in detail the assumptions considered for each equation with the end goal 279 of constructing the full model. A schematic diagram of the mechanisms and interactions 280 considered are shown in Fig 7 (cellular level) and Fig 8 (subcellular level). A list of model state ${ }^{281}$ variables with their respective definitions and units is presented in Table 2.

\section{The vaccine}

The vaccine dosage in the model is composed of a certain concentration of an adjuvant and a 284 load of peptides previously for a specific individual patient. Adjuvant is necessary to prime or 285 'activate' immature dendritic cells to respond to endogenous and exogenous antigens and elicit 286 an immune response through the activation of $\mathrm{T}$ cells.

Let $p(t)$ represent the peptide concentration in a vaccine and $A_{d}(t)$ the adjuvant concentration in a vaccine deposited in the subcutaneous (sc) connective tissue (injection site) 289 at time $t$. We assume the vaccine concentration entering the tissue is instantaneously mixed 290 and is homogeneously distributed for all $t$. Also, it is assumed that the vaccine is 291 instantaneously absorbed by the body at time $t$, i.e., the vaccine's concentration is updated 292 


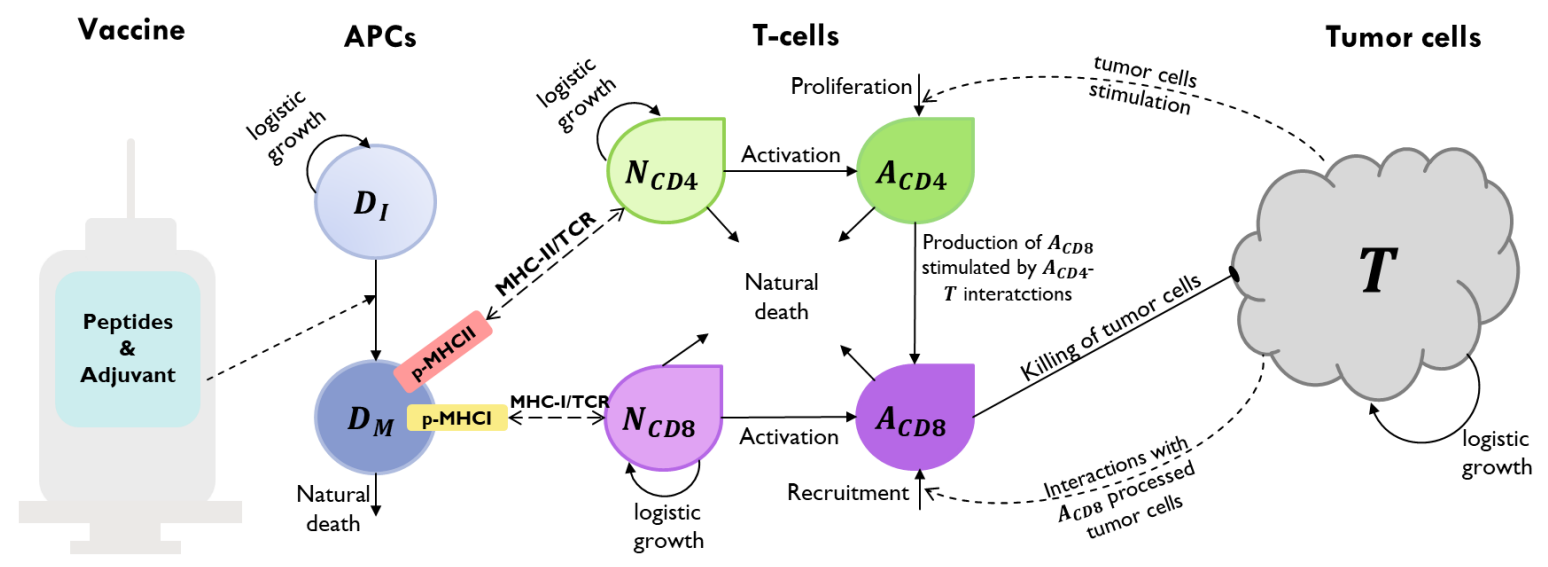

\begin{abstract}
$D_{I}:$ Immature dendritic cells $D_{M}$ : Mature dendritic cells
\end{abstract}

$N_{C D 4}$ : Naïve CD4+ T-cells

$N_{C D 8}$ : Naive CD8+ T-cells
$\boldsymbol{A}_{\mathrm{CD} 4}$ : Activated CD4+ T-cells $\boldsymbol{A}_{\text {CD8 }}$ : Activated CD8+ T-cells
$\boldsymbol{T}$ : Tumor cells

Fig 7. Schematic diagram of proposed mathematical model of the interactions between a human immune system and neoantigen cancer vaccines at the cellular level. Immature dendritic cells differentiate into mature dendritic cells due to the maturation signal provided by the adjuvant (dotted arrow). Upon antigen uptake, processing and presentation by the mature dendritic cells, naïve $\mathrm{T}$ cells recognize these (dashed lines with double-ended arrow-head) and differentiate into activated $\mathrm{T}$ cells that proliferate. Activated CD ${ }^{+} \mathrm{T}$ cells are now capable of killing tumor cells. Tumor lysis increase activated $\mathrm{T}$ cell counts through proliferation/recruitment (dotted curved arrows).

Table 2. Model equation variables with definition and units. Subscript $s=j$ for HLA-I allele and $s=k$ for HLA-II allele

\begin{tabular}{|c|c|c|c|}
\hline & Variable & Description & Unit \\
\hline \multirow{9}{*}{$\begin{array}{l}\frac{\tilde{\sigma}}{3} \\
\frac{\partial}{0} \\
\circlearrowright\end{array}$} & $p$ & Peptide concentration in a single vaccine & pmol \\
\hline & $A_{d}$ & Adjuvant concentration in a single vaccine & $\mathrm{mg} / \mathrm{L}$ \\
\hline & $D_{I}$ & Immature dendritic cell population & cells \\
\hline & $D_{M}$ & Mature dendritic cell population & cells \\
\hline & $N_{C D 4}$ & Naïve $\mathrm{CD} 4^{+} \mathrm{T}$ cell population & cells \\
\hline & $A_{C D 4}$ & Activated $\mathrm{CD} 4^{+} \mathrm{T}$ cell population & cells \\
\hline & $N_{C D 8}$ & Naïve $\mathrm{CD} 8^{+} \mathrm{T}$ cell population & cells \\
\hline & $A_{C D 8}$ & Activated $\mathrm{CD} 8{ }^{+} \mathrm{T}$ cell population & cells \\
\hline & $T$ & Tumor cell population & cells \\
\hline \multirow{5}{*}{ 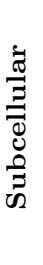 } & $p^{E}$ & Amount of endosomal peptide fragments & pmol \\
\hline & $M_{s}^{E}$ & Amount of endosomal MHC-I or MHC-II & pmol \\
\hline & $p M_{s}^{E}$ & Amount of endosomal p-MHCI/II complex & pmol \\
\hline & $p M_{s}$ & Amount of p-MHCI/II complex on DC membrane & pmol \\
\hline & $M_{s}$ & Amount of free MHC-I/II on DC membrane & pmol \\
\hline
\end{tabular}


before its content continues to be processed by dendritic cells. Since we consider that a vaccine 293 dosage is administered at different scheduled time points, the Dirac delta function $\delta$ allows the ${ }_{294}$ description of bolus repeated administration of the same vaccine dose at times $\tau_{i}, i=1, \ldots, n$ : 295

$$
h_{x}(t)=\sum_{i=1}^{n} \operatorname{Dose}_{x} \cdot \delta\left(t-\tau_{i}\right) \quad x=a, p
$$

where $\operatorname{Dose}_{x}, x=p, a$ is constant (specific to adjuvant or peptide concentration) and

$$
\begin{aligned}
\frac{d p}{d t} & =\underbrace{h_{p}(t)}_{\begin{array}{c}
\text { administered } \\
\text { peptide dose }
\end{array}}-\underbrace{\alpha_{p} p}_{\begin{array}{c}
\text { absorption of } \\
\text { peptides by the DCs }
\end{array}}, \\
\frac{d A_{d}}{d t} & =\underbrace{h_{a}(t)}_{\begin{array}{c}
\text { administered } \\
\text { adjuvant dose }
\end{array}}-\underbrace{\alpha_{d} A_{d}}_{\begin{array}{c}
\text { absorption of } \\
\text { adjuvant by DCs }
\end{array}},
\end{aligned}
$$

where $\alpha_{p}$ and $\alpha_{d}$ is the absorption rate of peptides and adjuvant by both immature and mature 301 dendritic cells, respectively.

\section{Antigen-presenting cells: dendritic cells (DCs)}

We assumed that immature dendritic cells, $D_{I}(t)$, located at the subcutaneous connective tissue 304 grow logistically with a maximum rate $\Lambda$ and carrying capacity $K_{D C}$. Mature dendritic cells 305 are assumed to die naturally with a rate $\delta_{M}$.

Immature dendritic cells, $D_{I}(t)$, can differentiate into mature dendritic cells, $D_{M}(t)$, with a 307 maximum differentiation rate of $r_{D}$ in the absence of peptides and adjuvant. However, the 308 maturation of DCs increases as a result of the contents of the vaccine. It is known that 309 adjuvant increases the maturation of dendritic cells [39]. Thus, we consider an external 
maturation signal given by the effects of the adjuvant in the vaccine. In this case, the 311 maturation signal is given by the release/absorption of adjuvant concentration, $A_{d}(t)$, in a 312 vaccine, meaning, higher $A_{d}(t)$ concentration causes higher cell maturation, hence, larger 313 mature dendritic cell, $D_{M}(t)$, population size. When the concentration $A_{d}(t)$ is equal to $K_{a}$, a 314 half-maximum effect constant, the maturation rate becomes $\frac{r_{D}}{2}$. Given these biological 315 assumptions, the equations describing the rate of change of immature dendritic cells, $D_{I}(t)$, and 316 mature dendritic cells, $D_{M}(t)$, are as follows:

$$
\begin{aligned}
\frac{d D_{I}}{d t} & =\underbrace{\Lambda D_{I}\left(1-\frac{D_{I}}{K_{D C}}\right)}_{\text {logistic growth }}-\underbrace{\frac{r_{D} A_{d}}{K_{a}+A_{d}} D_{I}}_{\begin{array}{c}
\text { maturation due to } \\
\text { adjuvant uptake }
\end{array}} \\
\frac{d D_{M}}{d t} & =\frac{r_{D} A_{d}}{K_{a}+A_{d}} D_{I}-\underbrace{\delta_{M} D_{M}}_{\text {natural death }}
\end{aligned}
$$

\section{Antigen processing and presentation by mature DCs}

The following modeling approach follows a similar modeling framework of [40,41]. The antigen 319 processing and presenting by mature dendritic cells take place at the subcellular level (see 320 Fig 8), in the endosomes of mature DCs. The vaccine peptides, $p(t)$, are endocytosed into 321 endosomes at a rate $\alpha_{p}^{E} \frac{V_{E}}{V_{s c}}$, where $\frac{V_{E}}{V_{s c}}$ is a re-scaling factor of the volume of endosomes in a 322 single DC, $V_{E}$, and the volume of the injection site $V_{s c}$. Therefore, peptides in DC's endosomes ${ }_{323}$ are represented by a single molecular specie $p^{E}(t)$.

Inside the endosomes and other specialized vesicular compartments, peptides interact with 325 MHC molecules of class I and/or class II. The strength of interaction of $p^{E}(t)$ and MHC 326 molecule allele $s$ is dictated by the effective disassociation constant $K_{D, s}^{\text {eff }}$ which gives the 327 relationship between $k_{\mathrm{off}, s}$, the off-rate, and $k_{\mathrm{on}, s}$, the bio-molecular on-rate. The dissociation 328 constant is defined as $K_{D, s}=k_{\mathrm{off}, s} / k_{\mathrm{on}, s}$.

Endosomal peptides, $p^{E}(t)$, bind to either MHC-I or MHC-II molecules in the endosomes, 330 $M_{s}^{E}(t)$ with allele $s=j$ or $k$, at a rate $k_{\mathrm{on}, s}$, to form endosomal peptide-MHC-I (p-MHCI) or $\quad 331$ 


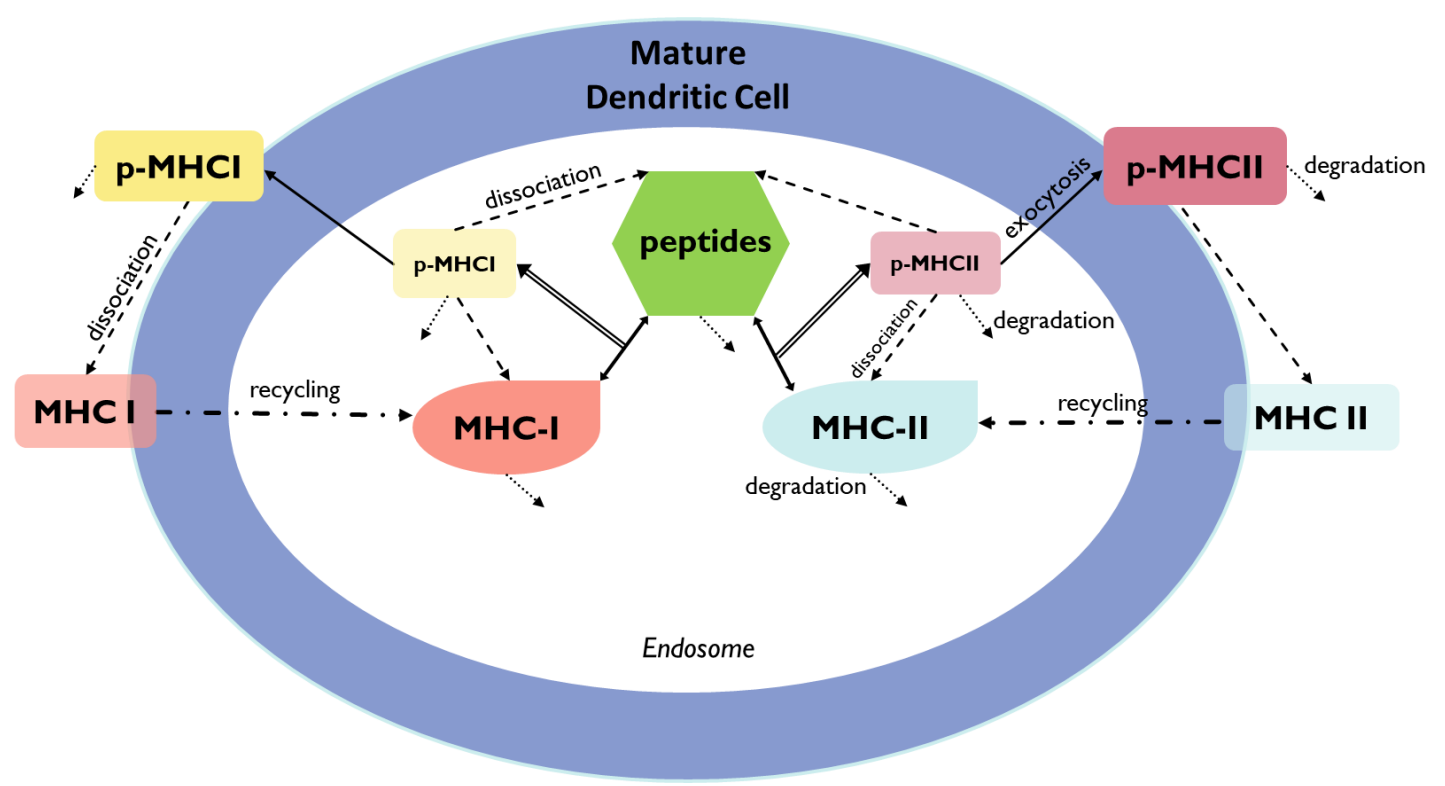

Fig 8. Schematic diagram of the mathematical model at the subcellular level.

Mature DCs uptake peptides, which are then processed through the interaction with major histocompatibility complex (MHC) class I and II to produce peptide-MHC complexes (p-MHC). These p-MHCs are then presented in the DC membrane for further recognition by naïve $\mathrm{T}$ cells. Peptides, MHC and p-MHC complexes can suffer degradation. Peptide-MHC complexes have the potential to dissociate back into their constituents. MHC molecules on the DC membrane can be recycled back into the endosome. Double line arrows connecting to double head arrows represent the interaction of peptide with MHC-I or MHC-II molecules to create p-MHCI or p-MHCII complexes. Short dotted arrows represent degradation for peptides, MHC-I/II, and p-MHCI/II in the endosome and on the cell membrane. Dashed arrows represent dissociation of peptide-MHCs into peptide and MHCs molecules. Dash-dotted arrows represent the recycle of MHC complexes into the endosome after dissociation of p-MHCs on the cell membrane.

p-MHCII complexes, represented with $p M_{s}^{E}(t)$. Note that binding occurs with available $M_{s}^{E}(t) \quad 332$ in the endosomes; thus, we consider a re-scaling factor of $\frac{1}{V_{E}}$. The p-MHCs may dissociate back 333 into their respective components, peptide and $\mathrm{MHC}$ molecule, at a rate $k_{\mathrm{off}, s} / V_{E}$. Also, the 334 peptide fragments that cannot bind with an MHC molecule are further processed into its amino 335 acids at rate $\beta_{p}$.

$$
\frac{d p^{E}}{d t}=\alpha_{p}^{E} p \frac{V_{E}}{V_{s c}}-\underbrace{p^{E} \cdot \sum_{s} k_{\mathrm{on}, s} \cdot \frac{M_{s}^{E}}{V_{E}}}_{\text {binding to MHCI/II }}+\underbrace{\sum_{s} k_{\mathrm{off}, s} \cdot p M_{s}^{E}}_{\text {dissociation of } \mathrm{p}-\mathrm{MHCI} / \mathrm{II}}-\underbrace{\beta_{p} p^{E}}_{\text {degradation }}
$$

To calculate $K_{D, s}^{\text {eff }}$, we follow a similar approach as in 40 . For each peptide-based vaccine 337 
sequence, we first obtain all $N$ (15-30)-mer peptides and their individual MHC-I/II binding 338 affinities $K_{D m}, m=1, \ldots, N$, from NetMHCpan 4.0 [42] and NetMHCIIpan 4.0 [43, 339 respectively. Then, those (15-30)-mers are pooled into a single representative molecule that 340 binds to MHC-I allele type $j$ and an MHC-II allele type $k$ with an 'effective disassociation ${ }^{341}$ constant' such that

$$
K_{D, s}^{\mathrm{eff}}=\left(\sum_{m=1}^{N} \frac{1}{K_{D m, s}}\right)^{-1}, \quad s=j, k
$$

The molecular population dynamics of the endosomal free MHC-I/II molecules, $M_{s}^{E}(t), \quad{ }_{343}$ $s=j, k$, is given by Eq. (6), in which we assume: (1) homeostatic growth of endosomal free 344 MHC-I/II molecules, with growth rate $\beta_{M}$, and $M_{s}^{E}(0)$ is the total number of MHC-I/II 345 molecules at $t=0 ;(2)$ binding on and off between $p^{E}(t)$ and MHCI/II molecules in the 346 endosomes, $M_{s}^{E}(t)$; (3) recycling of free MHC-I/II from the cell membrane back into the DC's 347 endosomes with rate $k_{\text {in }}$.

$$
\frac{d M_{s}^{E}}{d t}=\underbrace{\beta_{M}\left(M_{s}^{E}(0)-M_{s}^{E}\right)}_{\text {homeostatic growth }}+\underbrace{-k_{\mathrm{on}, s} \cdot p^{E} \frac{M_{s}^{E}}{V_{E}}+k_{\mathrm{off}, s} \cdot p M_{s}^{E}}_{\text {binding between } p^{E} \text { 's and } M_{s}^{E} \text { 's }}+\underbrace{k_{\mathrm{in}} \cdot M_{s}}_{\begin{array}{c}
\text { recycling of } \\
\text { free MHC-I/II }
\end{array}}
$$

Equation (7) describes the molecular population dynamics of endosomal p-MHCI/II allele $j \quad 349$ or $k, p M_{s}^{E}(t) s=j, k$, starting with the formation of p-MHCI/II complex. These can dissociate 350 back into peptides and $\mathrm{MHC}$ components, degrade at a rate $\beta_{p M}$, or get trafficked out at a rate 351 $k_{\text {ext }}$ to form membranal p-MHCs, $p M_{s}(t)$, which will be recognized by T cells. 352

$$
\frac{d p M_{s}^{E}}{d t}=\underbrace{k_{\mathrm{on}, s} \cdot p^{E} \frac{M_{s}^{E}}{V_{E}}-k_{\mathrm{off}, s} \cdot p M_{s}^{E}}_{\text {formation and dissociation of } p M_{s}^{E}}-\underbrace{\beta_{p M} \cdot p M_{s}^{E}}_{\text {degradation }}-\underbrace{k_{\text {ext }} p M_{s}^{E}}_{\begin{array}{c}
\text { exocytosis of } p M_{s}^{E} \\
\text { onto cell membrane }
\end{array}}
$$

Moreover, the p-MHCs on the DC membrane can dissociate into free MHCs on the cell 
membranes, $M_{s}(t)$, at a rate $k_{\text {off }}$ as in Eq. (8) and (9).

$$
\begin{aligned}
\frac{d p M_{s}}{d t} & =\underbrace{k_{\text {ext }} \cdot p M_{s}^{E}}_{\text {formation of } p M_{s}}-\underbrace{k_{\text {off,s } s} \cdot p M_{s}}_{\text {dissociation of } p M_{s}} \\
\frac{d M_{s}}{d t} & =\underbrace{k_{\text {off }, s} \cdot p M_{s}}_{\begin{array}{c}
\text { formation of } M_{s} \\
\text { from dissociated } p M_{s}
\end{array}}-\underbrace{k_{\mathrm{in}} \cdot M_{s}}_{\begin{array}{c}
\text { recycling of } \\
\text { free MHC-I/II }
\end{array}}
\end{aligned}
$$

Let $p M_{n}$, with $n=\mathrm{I}$, II representing the MHC class I or II, denote the number of p-MHC 355 molecules recognizable by the neoantigen-specific $\left(\mathrm{CD} 4^{+}\right.$or $\left.\mathrm{CD}^{+}\right) \mathrm{T}$ cells, such that

$$
p M_{n}(t)=N_{A} \cdot \sum_{s} p M_{s}(t) \cdot 10^{-12}, \quad s=j, k \quad n=\mathrm{I}, \mathrm{II},
$$

where $N_{A}$ is Avogadro's constant.

\section{Tumor cells}

The total number of tumor cells at time $t, T(t)$, is assumed to increase in a logistic fashion in the absence of immune intervention, where $r$ is the maximum tumor growth rate and $K_{T}$ is the

$$
\frac{d T}{d t}=\underbrace{r T\left(1-\frac{T}{K_{T}}\right)}_{\text {cell growth }}-\underbrace{\mathcal{D} T}_{\begin{array}{c}
\text { elimination by } \\
\text { activated } \mathrm{CD} 8^{+} \mathrm{T} \text { cells }
\end{array}}
$$

where $\mathcal{D}=d \frac{\left(\frac{A_{C D 8}}{T}\right)^{\lambda}}{s+\left(\frac{A_{C D 8}}{T}\right)^{\lambda}} ; \lambda$ represents how the lysis rate depends on the effector/target ratio, and $s$ affects the steepness of the curve, or how fast maximum killing rate is achieved. This expression is known as dePillis-Radunskaya Law (see [15,31] for more details), which has been 366 used extensively in the literature. 
Naïve $\mathrm{CD}^{+}$and $\mathrm{CD} 8^{+} \mathrm{T}$ cells are assumed to grow logistically (death regulated by carrying 369 capacity), with maximum growth rate $b_{4}$ and $b_{8}$, and carrying capacity $K_{T C 4}$ and $K_{T C 8}, \quad 370$ respectively. Activated T cell population increases if there is a 'successful' activation process. 371 Both naïve and activated $\mathrm{T}$ cells are assumed to die naturally with a rate $\mu$ (for both types of 372 naïve $\mathrm{T}$ cells), $\mu_{4}$ (for activated $\mathrm{CD} 4^{+} \mathrm{T}$ cells), and $\mu_{8}$ (for activated $\mathrm{CD} 8^{+} \mathrm{T}$ cells). 373

The total number of naïve $\mathrm{CD} 4^{+}$and $\mathrm{CD} 8^{+} \mathrm{T}$ cells at time $t$ is denoted with $N_{C D 4}(t)$ and 374 $N_{C D 8}(t)$, respectively. Naïve T cells can recognize neoantigen fragments presented on mature 375 DCs' membrane $\left(p M_{n}, n=\mathrm{I}\right.$, II) at any time $t$, represented with the product $F_{P_{i}} N_{C D i}(t)$, where 376 $F_{P_{i}}, i=4,8$, is the frequency of neoantigen-specific $\mathrm{CD} 4^{+}\left(\right.$or $\left.\mathrm{CD} 8^{+}\right) \mathrm{T}$ cells. Naïve $\mathrm{CD} 4^{+}$and 377 $\mathrm{CD}^{+} \mathrm{T}$ cells can be activated with a maximum activation rate of $\sigma_{4}$ and $\sigma_{8}$, respectively. The 378 rate of change of naïve $\mathrm{CD}^{+}\left(\right.$or $\mathrm{CD}^{+}$) $\mathrm{T}$ cell population is modeled with the following 379 equation:

$$
\frac{d N_{C D i}}{d t}=\underbrace{b_{i} N_{C D 4 i}\left(1-\frac{N_{C D i}}{K_{T C i}}\right)}_{\text {logistic growth }}-\underbrace{\sigma_{i} F_{P i} N_{C D i} \Psi_{i}}_{\begin{array}{c}
\text { activation via interaction } \\
\text { with mature DC }
\end{array}}-\underbrace{\mu N_{C D i}}_{\text {natural death }}, \quad i=4,8
$$

where, for example for $i=4, \Psi_{4}=\Psi_{4}\left(D_{M}, N_{C D 4}, A_{C D 4}\right)$, denotes the activation of neoantigen-specific precursor $\mathrm{T}$ cells dependent on the relative quantity of the mature dendritic 382 cells to naïve and activated $\mathrm{CD} 4^{+} \mathrm{T}$ cells and the number of p-MHCII complexes,

$$
\Psi_{4}=\left(\frac{D_{M}}{D_{M}+F_{P_{4}} N_{C D 4}+A_{C D 4}}\right)\left(\frac{p M_{\mathrm{II}}}{p M_{\mathrm{II}}+K_{p M}}\right)
$$

where $p M_{\mathrm{II}}$ represents the number of p-MHCII molecules recognizable by the neoantigen-specific CD4 ${ }^{+} \mathrm{T}$ cells as described in Eq. (10). The strength of mature DCs, $D_{M}(t), \quad 385$ to activate a neoantigen-specific $\mathrm{CD} 4^{+} \mathrm{T}$ cell is $50 \%$ when $p M_{\mathrm{II}}(t)$ is equal to $K_{p M}$ and 386 increases as $p M_{\mathrm{II}}(t)$ increases. 


$$
A_{T C}(t)=A_{C D 4}(t)+A_{C D 8}(t)
$$

where $A_{C D 4}(t)$ and $A_{C D 8}(t)$ denote the population of activated CD4 ${ }^{+}$and $\mathrm{CD} 8^{+} \mathrm{T}$ cells, ${ }_{389}$ respectively. These cell populations increase with the activation of naïve $\mathrm{CD} 4^{+}\left(\right.$or $\left.\mathrm{CD} 8^{+}\right) \mathrm{T}$ cells that had a 'successful' interaction with a mature DC. Activated T cells undergo 391 proliferation or differentiation, depending on the proportion between $D_{M}(t)$, cell types involved 392 in the activation $\left(F_{P_{i}} N_{C D i}(t), D_{M}(t)\right.$ and $\left.A_{C D i}(t)\right)$, and the number of T-epitope-MHC on 393 $D_{M}(t)$ 's, i.e., $p M_{\mathrm{I}}(t)$ or $p M_{\mathrm{II}}(t)$. The interaction of mature dendritic cells and activated $\mathrm{CD} 4^{+}{ }^{394}$ (or $\mathrm{CD}^{+}$) $\mathrm{T}$ cells is described with the function:

$$
\Phi_{i}=\left(\frac{D_{M}}{D_{M}+F_{P_{i}} N_{C D i}+A_{C D i}}\right)\left(\frac{p M_{n}-K_{p M}}{p M_{n}+K_{p M}}\right), \quad i=4,8, \quad n=\mathrm{I}, \mathrm{II} .
$$

To understand this interaction better, for example, when the quantity $p M_{\mathrm{II}}(t)$ at any time $t$ is 396 much larger than $K_{p M}$, then the ratio $\frac{p M_{\mathrm{II}}-K_{p M}}{p M_{\mathrm{II}}+K_{p M}} \rightarrow 1$, i.e., most cells proliferate. In a similar 397 way, when $p M_{\mathrm{II}}(t)$ is much smaller than $K_{p M}$, then the ratio $\frac{p M_{\mathrm{II}}-K_{p M}}{p M_{\mathrm{II}}+K_{p M}} \rightarrow-1$, which implies 398 most activated $\mathrm{CD} 4^{+} \mathrm{T}$ cells differentiate (i.e., cells are removed from this species 399 compartment). The rate of change of activated $\mathrm{CD} 4^{+} \mathrm{T}$ cell population is modeled with the 400 following equation:

$$
\begin{aligned}
\frac{d A_{C D 4}}{d t} & =\underbrace{\sigma_{4} F_{P_{4}} N_{C D 4} \Psi_{4}}_{\begin{array}{c}
\text { activation via interaction } \\
\text { with mature DC }
\end{array}}+\underbrace{\rho_{4} \Phi_{4} A_{C D 4}}_{\begin{array}{c}
\text { proliferation/ } \\
\text { differentiation of } A_{C D 4}
\end{array}} \\
+ & \underbrace{c_{4} A_{C D 4}^{\frac{T}{a_{1}+T}}-\underbrace{\mu_{4} A_{C D 4}}_{\text {natural death }}}_{\begin{array}{c}
\text { probability of } \\
\text { efficient proliferation }
\end{array}},
\end{aligned}
$$

We assume an activating effect of $\mathrm{CD}^{+} \mathrm{T}$ cells due to existence of tumor cells represented ${ }_{402}$ by the third term in equation (13). This immune system's response is described mathematically ${ }_{403}$ 
with a Michaelis-Menten interaction term, where the parameter $c_{4}$ models the antigenicity of 404 the tumor. Antigenicity can be thought of as a measure of how different the tumor is from 'self'. 405 This functional (or phenomenological) response to model this interaction has been used in other 406 mathematical models such as 31, 44, 45.

The rate of change of activated $\mathrm{CD} 8^{+} \mathrm{T}$ cell population, $A_{C D 8}(t)$, is modeled as follows:

$$
\begin{aligned}
\frac{d A_{C D 8}}{d t} & =\underbrace{c \frac{\mathcal{D}^{2} T^{2}}{a+\mathcal{D}^{2} T^{2}} A_{C D 8}}_{\begin{array}{c}
\text { recruitment of CD8 } \\
\text { due to the presence of cells tumor }
\end{array}}+\underbrace{c_{8} A_{C D 4} T}_{\begin{array}{c}
\text { activation via } A_{C D 4} \\
\text { interaction with tumor cells }
\end{array}} \\
& +\underbrace{\sigma_{8} F_{P_{8}} N_{C D 8} \Psi_{8}}_{\begin{array}{c}
\text { activation via interaction } \\
\text { with mature DC }
\end{array}}+\underbrace{\rho_{8} \Phi_{8} A_{C D 8}}_{\begin{array}{c}
\text { proliferation/ } \\
\text { differentiation of } A_{C D 8}
\end{array}}-\underbrace{\mu_{8} A_{C D 8}}_{\text {natural death }}
\end{aligned}
$$

The first term of equation (14) represents the recruitment in $\mathrm{CD} 8^{+} \mathrm{T}$ cell population by be produced as result of activated $\mathrm{CD} 4^{+} \mathrm{T}$ cells interacting with tumor cells. The last three ${ }_{416}$ terms of equation (14) are similar to those described previously for the equation of $A_{C D 4}(t)$. ${ }_{417}$

\section{Model initial conditions and parameter values}

Our mathematical model specifies 18 initial conditions such as immune and malignant cell ${ }_{419}$ counts, neoantigen peptide concentrations, and adjuvant concentrations in a vaccine (S1 Table). ${ }_{420}$ We categorized the initial conditions into two groups, 'global' and 'patient-specific'. The global ${ }_{421}$ initial conditions (14 in total) are values that were found in the literature or estimated from 422 available population level data of several clinical or experimental studies which include: ${ }_{423}^{4}$ immature and mature DC counts, naïve T cell counts, concentrations of endosomal peptides 
medRxiv preprint doi: https://doi.org/10.1101/2021.01.08.21249452; this version posted June 6, 2021. The copyright holder for this preprint (which was not certified by peer review) is the author/funder, who has granted medRxiv a license to display the preprint in perpetuity. It is made available under a CC-BY-NC-ND 4.0 International license .

and $\mathrm{MHC} / \mathrm{p}-\mathrm{MHC}$ I and II molecules in DC's endosome and on DC membrane. Patient-specific ${ }_{425}$ initial conditions (four in total) were estimated from patient-specific data from six patients in a 426 personalized neoantigen anti-melanoma vaccine clinical trial (ClinicalTrials.gov: ${ }_{427}$ NCT01970358) [26]. These patient-specific initial conditions are the peptide and adjuvant ${ }_{428}$ concentrations in a vaccine, initial activated T cell counts, and initial tumor cell count. $\quad 429$ Detailed derivation of these estimates is provided in the Supplementary S1 Appendix. 430

Additionally, the model requires values for 45 parameters. A total of four model parameters 431 were directly estimated by fitting the analytical solution of the total activated T cells, $A_{T C}(t) \quad{ }^{432}$ of six patients. These parameters are $c$ : maximum $\mathrm{CD} 8^{+} \mathrm{T}$ cell recruitment rate; $c_{4}$ : maximum ${ }_{433}$ $\mathrm{CD}^{+} \mathrm{T}$ cell production rate; $d$ : maximum lysis rate by activated $\mathrm{T}$ cells; $\lambda$ : dependence of ${ }_{434}$ lysis rate on the effector/target ratio constant. We used the 'NonlinearModelFit' function in ${ }_{435}$ Mathematica Version 12.0 [49] with a constrained global optimization method ('NMinimize' ${ }_{436}$ with 'SimulatedAnnealing') for model parametrization. The goodness-of-fit was measured by ${ }_{437}$ the adjusted $R^{2}$. Other parameters such as peptide and adjuvant concentration in the vaccine ${ }_{438}$ and patient-specific HLA alleles, were predetermined based on information provided in [26]. 439 The detailed description of model parameters, parameter values/ranges found in the literature, 440 parameters estimates from model fitting and parameter values used to run our simulations were ${ }_{441}$ organized by cell and molecule species on the Supplementary S1 Table and marked accordingly: ${ }_{442}$ parameters and initial conditions directly obtained from the literature were labeled with $\boldsymbol{\beta}, \quad 443$ those estimated from published data (clinical trial or experiment) were labeled with $\downarrow$, and ${ }_{444}$ patient-specific parameters fitted individually to six patients' data from ClinicalTrials.gov: 445

NCT01970358 were labeled with $\star$. 446

\section{Sensitivity analysis}

We perform a global sensitivity analysis using Latin Hypercube Sampling (LHS) along with 448 Partial Rank Correlation Coefficient (PRCC) to assess the sensitivity of two outputs of interest, ${ }_{449}$ activated T cells, $A_{T C}$ and tumor cells, $T$, to the changes of the parameter values. In general, ${ }_{450}^{45}$ 
medRxiv preprint doi: https://doi.org/10.1101/2021.01.08.21249452; this version posted June 6, 2021. The copyright holder for this preprint (which was not certified by peer review) is the author/funder, who has granted medRxiv a license to display the preprint in perpetuity. It is made available under a CC-BY-NC-ND 4.0 International license .

the magnitude of the PRCC indicates the impact of the uncertainty of estimating input 451 parameter values for predicting the outcome variable, and the sign indicates the direction of 452 correlation between each input parameter and each output variable [28, 50].

PRCC values were calculated between for each of the four patient-specific parameters $\left(c, c_{4},{ }^{454}\right.$ $d, \lambda)$, as well as two patient initial condition inputs $N_{T C 0}$ and $T_{0}$ against two outputs of ${ }_{455}$ interest $\left(A_{T C}\right.$ and $\left.T\right)$ at specific time-points (days 25, 112, and 147). Through uncertainty ${ }_{456}$ quantification and sensitivity analysis, we determined which input parameters (see Table 1 for a ${ }_{457}$ list of estimated parameter values and Table 2 and the Supplementary S1 Table for definitions ${ }_{458}$ of the model variables and list of baseline parameters) are most influential on the outcome 459 variables of interest. We used the mean of the best-fit parameter values of all six patients in 460 Table 1 as the baseline to calculate LHS/PRCC values and the minimum and maximum of the ${ }_{461}$ best-fit parameter values to calculate the range of LHS/PRCC. Vaccine administration for all ${ }_{462}$ patients in the clinical trial [26] included a priming and a booster phase. We selected day 25463 ( $t=24$ in our simulation), to define the 'priming phase', since the last priming vaccination $\quad{ }_{464}$ in [26] occurred about 3 weeks in; day $112(t=111)$ as the 'peak $\mathrm{T}$ cell response' of activated T 465 cells (as observed in [26]); and day $147(t=146)$ as the 'end of treatment' since the last booster 466 vaccination occurred on week 20 .

\section{Acknowledgments}

This project was supported in part by an appointment to the Research Participation Program 469 at OBE/CBER, U.S. Food and Drug Administration, administered by the Oak Ridge Institute 470 for Science and Education through an interagency agreement between the U.S. Department of ${ }_{471}$ Energy and FDA. The authors received no financial support from any source, and there is no 472 conflict of interest. The authors thank Joanne Berger, FDA Library, for manuscript editing ${ }_{473}$ assistance. We also extend our gratitude to Dr. Angela M. Jimenez Valencia (FDA/CVM) for ${ }^{474}$ the discussions that helped improve this manuscript. 


\section{Author Contributions}

Conceptualization: MRM, ONY, ZES, HY

Data curation: MRM

Formal analysis: MRM

479

Funding acquisition: HY

480

Investigation: MRM, ONY

481

Methodology: MRM, ONY

482

Project administration: MRM, ONY, HY

Resources: HY

Supervision: HY, ZES

Visualization: MRM

Writing - Original draft: MRM, ONY, ZES, UN, JRM, HY

Writing - Review \& Editing: MRM, ONY, ZES, UN, JRM, HY

\section{Disclaimer}

\section{References}

1. Hollingsworth RE, Jansen K. Turning the corner on therapeutic cancer vaccines. NPJ Vaccines. 2019;4:7. doi:10.1038/s41541-019-0103-y.

2. Peng M, Mo Y, Wang Y, Wu P, Zhang Y, Xiong F, et al. Neoantigen vaccine: an emerging tumor immunotherapy. Mol Cancer. 2019;18(1):128.

doi:10.1186/s12943-019-1055-6. 
medRxiv preprint doi: https://doi.org/10.1101/2021.01.08.21249452; this version posted June 6, 2021. The copyright holder for this preprint (which was not certified by peer review) is the author/funder, who has granted medRxiv a license to display the preprint in perpetuity.

It is made available under a CC-BY-NC-ND 4.0 International license.

3. Bitton RJ, Guthmann MD, Gabri MR, Carnero AJL, Alonso DF, Fainboim L, et al. Cancer vaccines: An update with special focus on ganglioside antigens (Review). Oncol Rep. 2002;9(2):267-276. doi:10.3892/or.9.2.267.

4. Thomas S, Prendergast GC. Cancer Vaccines: A Brief Overview. Methods Mol Biol. 2016;1403:755-61. doi:10.1007/978-1-4939-3387-743.

5. Aldous AR, Dong JZ. Personalized neoantigen vaccines: A new approach to cancer immunotherapy. Bioorg Med Chem. 2018;26(10):2842-2849.

doi:10.1016/j.bmc.2017.10.021.

6. Aurisicchio L, Pallocca M, Ciliberto G, Palombo F. The perfect personalized cancer therapy: cancer vaccines against neoantigens. J Exp Clin Cancer Res. 2018;37(1):86. doi:10.1186/s13046-018-0751-1.

7. Hausser J, Szekely P, Bar N, Zimmer A, Sheftel H, Caldas C, et al. Tumor diversity and the trade-off between universal cancer tasks. Nat Commun. 2019;10(1):5423. doi:10.1038/s41467-019-13195-1.

8. Hu Z, Ott PA, Wu CJ. Towards personalized, tumour-specific, therapeutic vaccines for cancer. Nat Rev Immunol. 2018;18(3):168-182. doi:10.1038/nri.2017.131.

9. Jiang T, Shi T, Zhang H, Hu J, Song Y, Wei J, et al. Tumor neoantigens: from basic research to clinical applications. J Hematol Oncol. 2019;12(1):93.

doi:10.1186/s13045-019-0787-5.

10. Guo Y, Lei K, Tang L. Neoantigen Vaccine Delivery for Personalized Anticancer Immunotherapy. Front Immunol. 2018;9:1499. doi:10.3389/fimmu.2018.01499.

11. Yarchoan M, Johnson r B A, Lutz ER, Laheru DA, Jaffee EM. Targeting neoantigens to augment antitumour immunity. Nat Rev Cancer. 2017;17(9):569. doi:10.1038/nrc.2017.74.

12. Adam JA, Bellomo N. A survey of models for tumor-immune system dynamics. Springer Science Business Media; 2012. 
medRxiv preprint doi: https://doi.org/10.1101/2021.01.08.21249452; this version posted June 6, 2021. The copyright holder for this preprint (which was not certified by peer review) is the author/funder, who has granted medRxiv a license to display the preprint in perpetuity. It is made available under a CC-BY-NC-ND 4.0 International license .

13. dePillis LG, Eladdadi A, Radunskaya AE. Modeling cancer-immune responses to therapy. J Pharmacokinet Pharmacodyn. 2014;41(5):461-78. doi:10.1007/s10928-014-9386-9.

14. Anderson ARA, Maini PK. Mathematical Oncology. Bull Math Biol. 2018;80(5):945-953. doi:10.1007/s11538-018-0423-5.

15. d'Onofrio A, Gandolfi A, D’Onofrio A. Mathematical Oncology 2013. Springer; 2014.

16. Barbolosi D, Ciccolini J, Lacarelle B, Barlesi F, Andre N. Computational oncology-mathematical modelling of drug regimens for precision medicine. Nat Rev Clin Oncol. 2016;13(4):242-54. doi:10.1038/nrclinonc.2015.204.

17. Victori P, Buffa FM. The many faces of mathematical modelling in oncology. Br J Radiol. 2019;92(1093):20180856. doi:10.1259/bjr.20180856.

18. Wilson S, Levy D. A mathematical model of the enhancement of tumor vaccine efficacy by immunotherapy. Bull Math Biol. 2012;74(7):1485-500. doi:10.1007/s11538-012-9722-4.

19. Agur Z, Halevi-Tobias K, Kogan Y, Shlagman O. Employing dynamical computational models for personalizing cancer immunotherapy. Expert Opin Biol Ther. 2016;16(11):1373-1385. doi:10.1080/14712598.2016.1223622.

20. Castiglione F, Piccoli B. Cancer immunotherapy, mathematical modeling and optimal control. J Theor Biol. 2007;247(4):723-32. doi:10.1016/j.jtbi.2007.04.003.

21. Peng H, Zhao W, Tan H, Ji Z, Li J, Li K, et al. Prediction of treatment efficacy for prostate cancer using a mathematical model. Sci Rep. 2016;6:21599. doi:10.1038/srep21599.

22. Radunskaya A, de Pillis L, Gallegos A. A Model of Dendritic Cell Therapy for Melanoma. Frontiers in Oncology. 2013;3(56). doi:10.3389/fonc.2013.00056.

23. Radunskaya KRWIT A E. Mathematical Modeling of Tumor Immune Interactions: A Closer Look at the Role of a PD-L1 Inhibitor in Cancer Immunotherapy. Spora: A 
medRxiv preprint doi: https://doi.org/10.1101/2021.01.08.21249452; this version posted June 6, 2021. The copyright holder for this preprint

(which was not certified by peer review) is the author/funder, who has granted medRxiv a license to display the preprint in perpetuity.

It is made available under a CC-BY-NC-ND 4.0 International license .

Journal of Biomathematics. 2018;4(1):25-41.

doi:http://doi.org/10.30707/SPORA4.1Radunskaya.

24. de Pillis LG, Gu W, Radunskaya AE. Mixed immunotherapy and chemotherapy of tumors: modeling, applications and biological interpretations. J Theor Biol.

2006;238(4):841-62. doi:10.1016/j.jtbi.2005.06.037.

25. Lai X, Friedman A. Combination therapy of cancer with cancer vaccine and immune checkpoint inhibitors: A mathematical model. PLoS One. 2017;12(5):e0178479. doi:10.1371/journal.pone.0178479.

26. Ott PA, Hu Z, Keskin DB, Shukla SA, Sun J, Bozym DJ, et al. An immunogenic personal neoantigen vaccine for patients with melanoma. Nature. 2017;547(7662):217-221. doi:10.1038/nature22991.

27. Stark PB. SticiGui, Onsophic, and Statistics W21. University of California, Berkeley. $2011 ;$

28. Blower SM, Dowlatabadi H. Sensitivity and uncertainty analysis of complex models of disease transmission: an HIV model, as an example. International Statistical Review/Revue Internationale de Statistique. 1994; p. 229-243.

29. Butterfield LH. Cancer vaccines. BMJ. 2015;350:h988. doi:10.1136/bmj.h988.

30. Tay RE, Richardson EK, Toh HC. Revisiting the role of CD4+ T cells in cancer immunotherapy — new insights into old paradigms. Cancer Gene Therapy. 2020; p. 1-13.

31. de Pillis LG, Radunskaya AE, Wiseman CL. A validated mathematical model of cell-mediated immune response to tumor growth. Cancer Res. 2005;65(17):7950-8. doi:10.1158/0008-5472.CAN-05-0564.

32. Vaghi C, Rodallec A, Fanciullino R, Ciccolini J, Mochel JP, Mastri M, et al. Population modeling of tumor growth curves and the reduced Gompertz model improve prediction of the age of experimental tumors. PLoS computational biology. 2020;16(2):e1007178. 
medRxiv preprint doi: https://doi.org/10.1101/2021.01.08.21249452; this version posted June 6, 2021. The copyright holder for this preprint (which was not certified by peer review) is the author/funder, who has granted medRxiv a license to display the preprint in perpetuity.

It is made available under a CC-BY-NC-ND 4.0 International license .

33. Benzekry S, Lamont C, Beheshti A, Tracz A, Ebos JM, Hlatky L, et al. Classical mathematical models for description and prediction of experimental tumor growth. PLoS Comput Biol. 2014;10(8):e1003800.

34. Lopez AG, Seoane JM, Sanjuan MA. A validated mathematical model of tumor growth including tumor-host interaction, cell-mediated immune response and chemotherapy. Bull Math Biol. 2014;76(11):2884-906. doi:10.1007/s11538-014-0037-5.

35. Society AC. Melanoma Skin Cancer Stages; 2019. Available from: https://www. cancer.org/cancer/melanoma-skin-cancer/ detection-diagnosis-staging/melanoma-skin-cancer-stages.html.

36. Gao JQ, Okada N, Mayumi T, Nakagawa S. Immune cell recruitment and cell-based system for cancer therapy. Pharmaceutical research. 2008;25(4):752-768.

37. Matsuzaki J, Tsuji T, Luescher IF, Shiku H, Mineno J, Okamoto S, et al. Direct tumor recognition by a human CD4+ T-cell subset potently mediates tumor growth inhibition and orchestrates anti-tumor immune responses. Scientific reports. 2015;5(1):1-14.

38. Palucka K, Banchereau J. Dendritic-Cell-Based Therapeutic Cancer Vaccines. Immunity. 2013;39(1):38-48. doi:10.1016/j.immuni.2013.07.004.

39. Walker J, Tough DF. Modification of TLR-induced activation of human dendritic cells by type I IFN: synergistic interaction with TLR4 but not TLR3 agonists. Eur J Immunol. 2006;36(7):1827-36. doi:10.1002/eji.200635854.

40. Yogurtcu ON, Sauna ZE, McGill JR, Tegenge MA, Yang H. TCPro: an In Silico Risk Assessment Tool for Biotherapeutic Protein Immunogenicity. The AAPS journal. 2019;21(5):96.

41. Chen X, Hickling T, Vicini P. A mechanistic, multiscale mathematical model of immunogenicity for therapeutic proteins: part 1-theoretical model. CPT: pharmacometrics \& systems pharmacology. 2014;3(9):1-9. 
medRxiv preprint doi: https://doi.org/10.1101/2021.01.08.21249452; this version posted June 6, 2021. The copyright holder for this preprint (which was not certified by peer review) is the author/funder, who has granted medRxiv a license to display the preprint in perpetuity. It is made available under a CC-BY-NC-ND 4.0 International license .

42. Jurtz V, Paul S, Andreatta M, Marcatili P, Peters B, Nielsen M. NetMHCpan-4.0: improved peptide-MHC class I interaction predictions integrating eluted ligand and peptide binding affinity data. The Journal of Immunology. 2017;199(9):3360-3368.

43. Reynisson B, Barra C, Kaabinejadian S, Hildebrand WH, Peters B, Nielsen M. Improved prediction of MHC II antigen presentation through integration and motif deconvolution of mass spectrometry MHC eluted ligand data. Journal of Proteome Research. 2020;.

44. de Pillis LG, Gu W, Radunskaya AE. Mixed immunotherapy and chemotherapy of tumors: modeling, applications and biological interpretations. J Theor Biol.

2006;238(4):841-62. doi:10.1016/j.jtbi.2005.06.037.

45. de Pillis LG, Radunskaya A. - A mathematical model of immune response to tumor invasion. In: Bathe KJ, editor. Computational Fluid and Solid Mechanics 2003. Oxford: Elsevier Science Ltd; 2003. p. 1661 - 1668. Available from: http://wWW.sciencedirect.com/science/article/pii/B9780080440460504048.

46. de Pillis LG, Radunskaya A. - Modeling Tumor-Immune Dynamics. In: Eladdadi A MD Kim P, editor. Mathematical Models of Tumor-Immune System Dynamics. New York, NY: Springer Proceedings in Mathematics Statistics; 2014. p. 59-108.

47. Ghaffari A, Bahmaie B, Nazari M. A mixed radiotherapy and chemotherapy model for treatment of cancer with metastasis. Mathematical methods in the applied sciences. 2016;39(15):4603-4617.

48. Borst J, Ahrends T, Babała N, Melief CJ, Kastenmüller W. CD4+ T cell help in cancer immunology and immunotherapy. Nature Reviews Immunology. 2018;18(10):635-647.

49. Mathematica, Version 12.0;. Available from: https://www.wolfram.com/mathematica.

50. Marino S, Hogue IB, Ray CJ, Kirschner DE. A methodology for performing global uncertainty and sensitivity analysis in systems biology. J Theor Biol. 2008;254(1):178-96. doi:10.1016/j.jtbi.2008.04.011. 


\section{Supplementary information}

S1 Appendix. Mathematical details, parameter estimation, table of model parameter values and definitions, and additional results.

S1 Table. Parameter values and definition. Mathematical model parameter definitions, value ranges, and values used in simulations.

S1 Code. Mathematica Notebook. The code to the replicate time series simulations of the presented model is available for review in https://github.com/marisabel19/CancerVaxModel2021. 